\title{
البـنْ: 10
}

التوجهات المستقبلية لتمديث براهمج التدريب عن بعد ودورها في

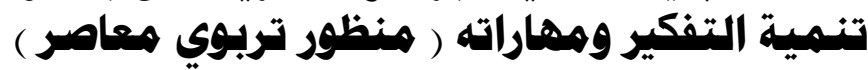

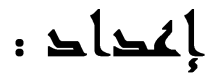

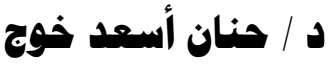

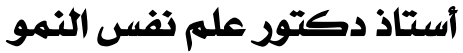 \\ كليت الآداب والعلوم الإنسانيت جامعت الملكك عبد العزيز بجدة
}





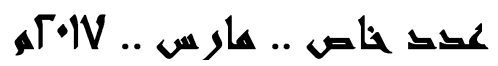

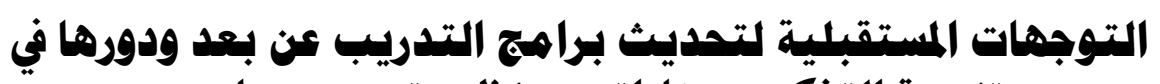

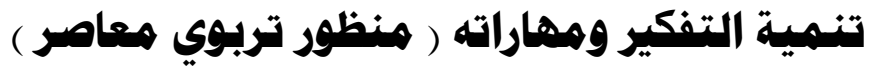

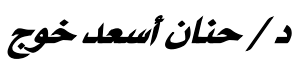 \\ أستاذ دكتور علم نفس النهو النهو \\ كليت الآداب والعلوم الإنسانيت جامعت البلك عبد العزيزيجلة
}

•

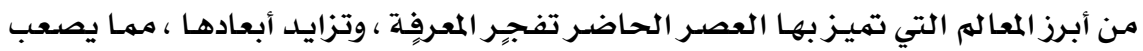

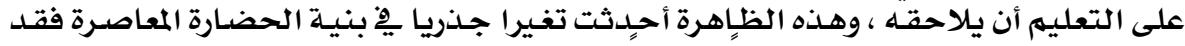

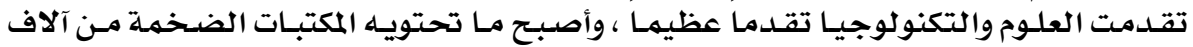

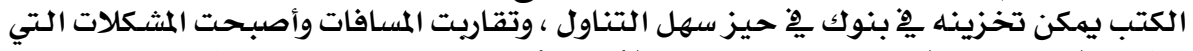

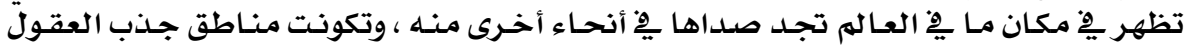

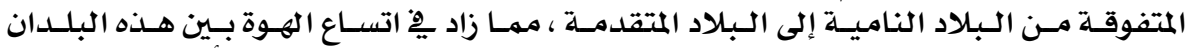

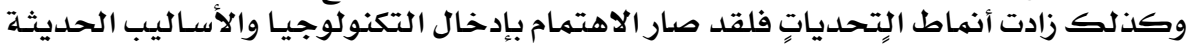

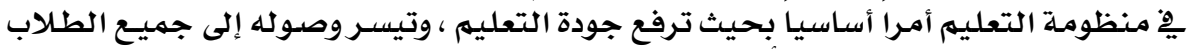

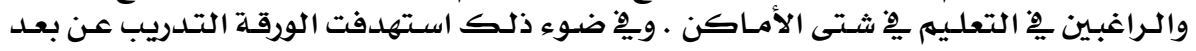

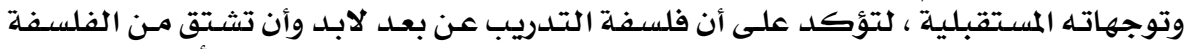

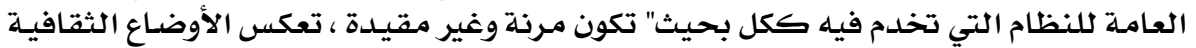

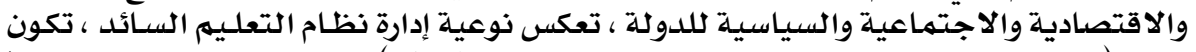

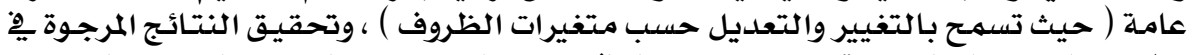

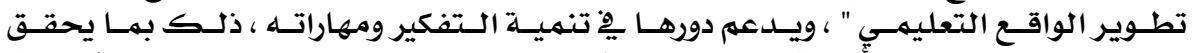

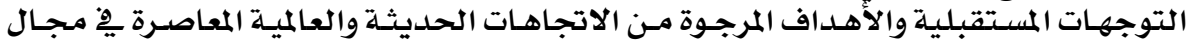

التدريب التوجنات

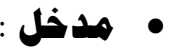

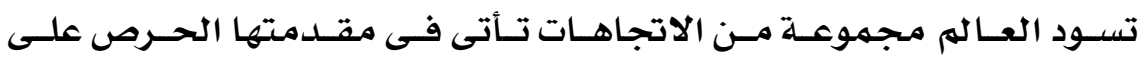
التجديد والتطوير فى مهـال تدريب المعلهم أثناء الخدمـة بحيـث تلبـى احتيـاجـات

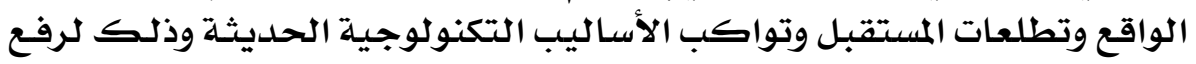

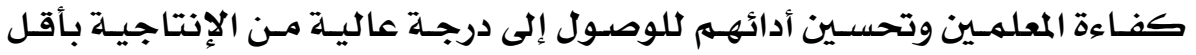

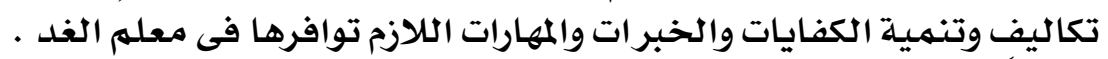

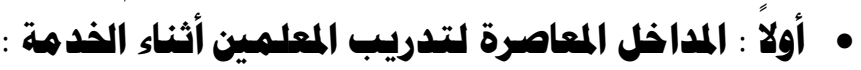

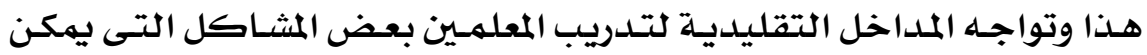

تصنيفها على أربح فئات رئيسيـة هـى (

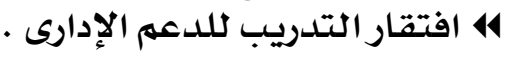

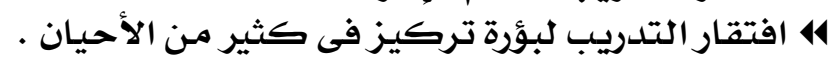

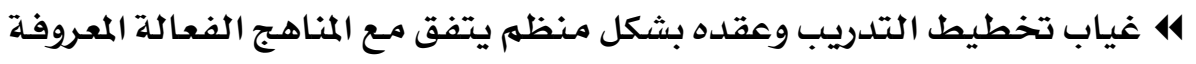
كتصهيم التدريب .

\section{$\varepsilon \odot 9$}


4 ضعف الربط بفعالية بين التدريب والمبادرات التنظيمية الأخرى .

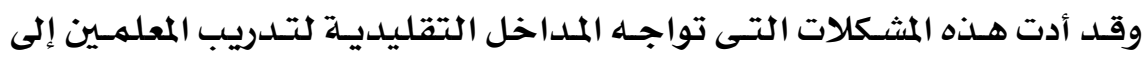

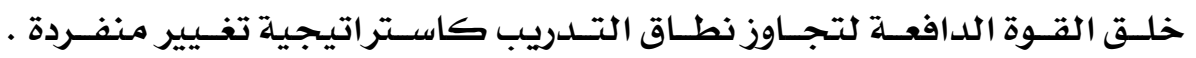

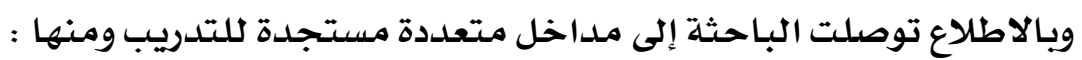

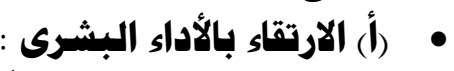

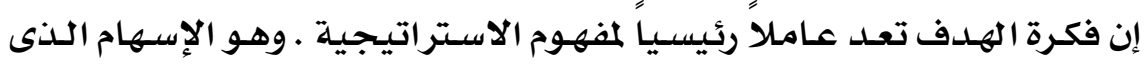

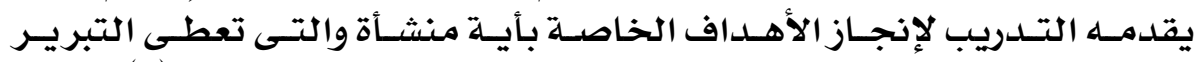

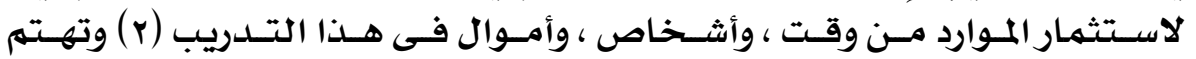

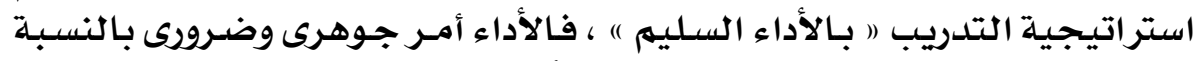

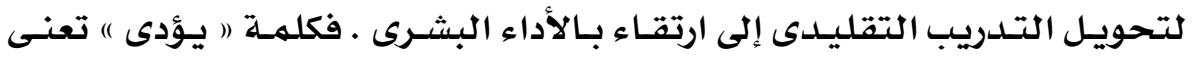

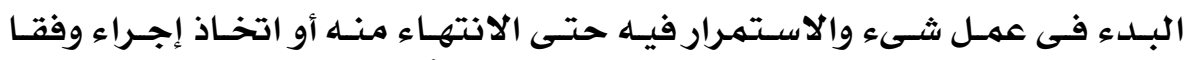

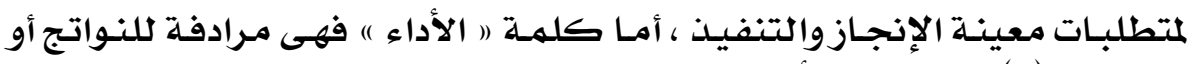

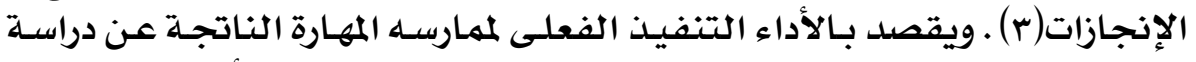

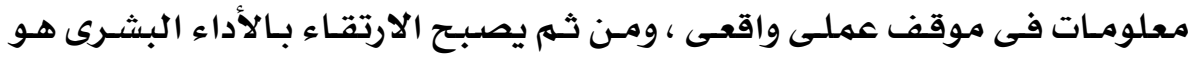

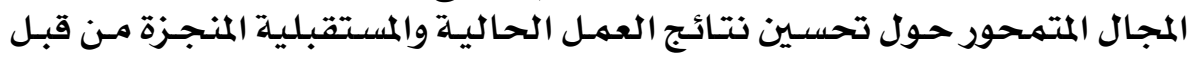
المعلمين فى المدارس على نحول تحو منظم .

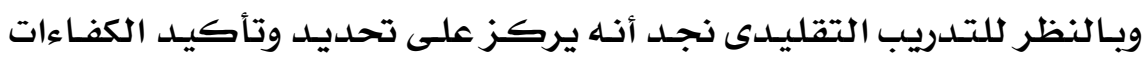

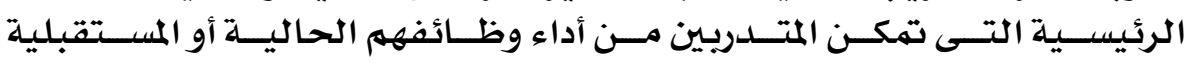

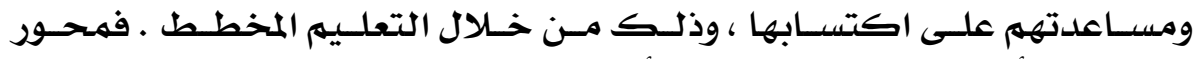

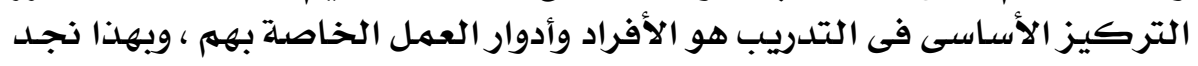

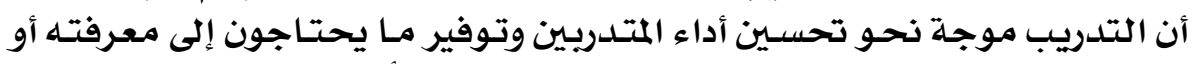

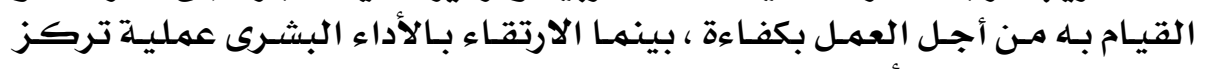

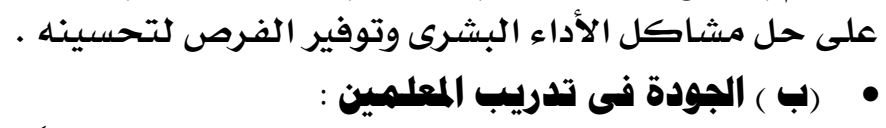

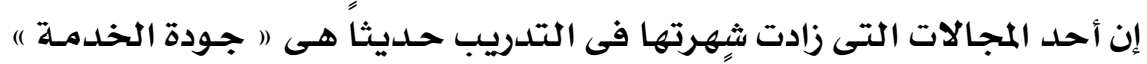

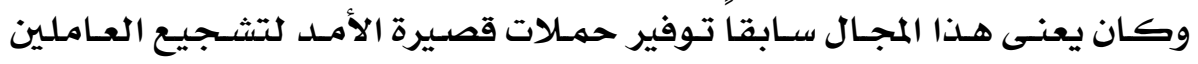

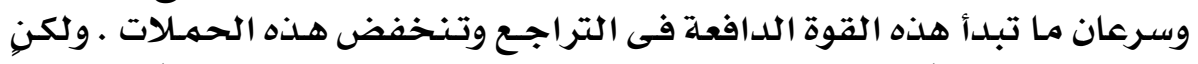

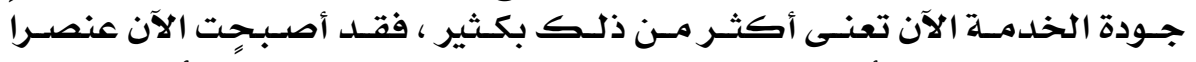

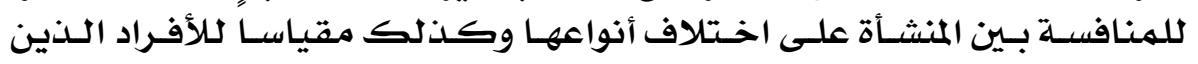

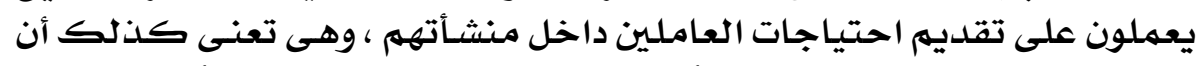

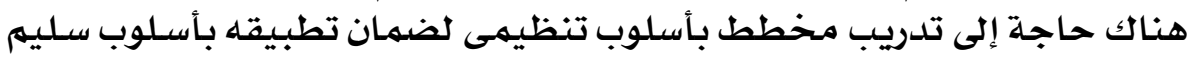
هذا إلى جانب الحاجة لالتزام مستمر وشامل من كل فرئل فرد يعمل في المنشأة

\section{$\varepsilon 7$.}




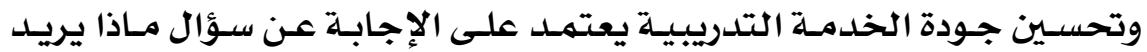

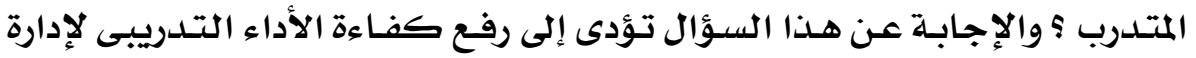

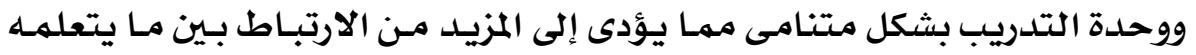

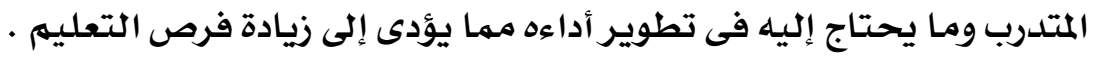

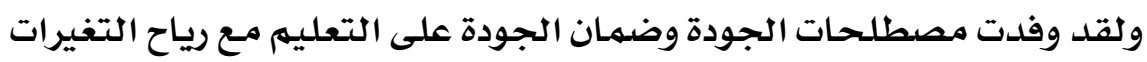

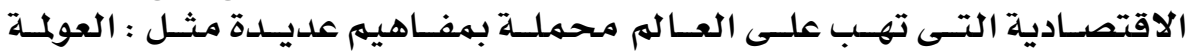

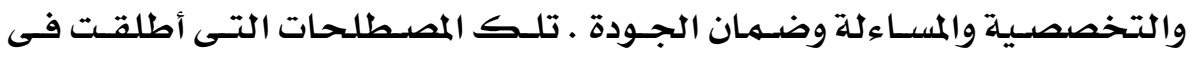

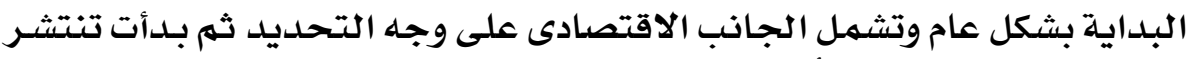

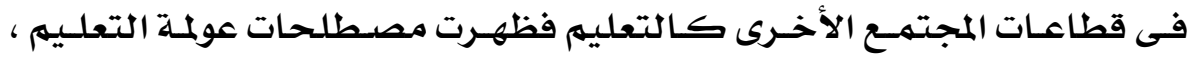

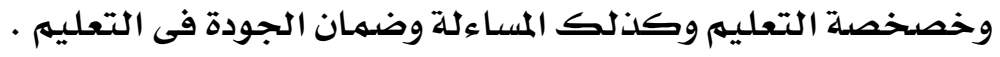

وفى هذا الصدد يمكن تحديد بعض المصطلحات الأساسية التى يحسدث بينها

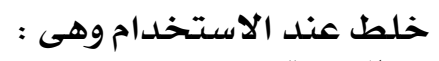

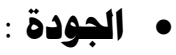

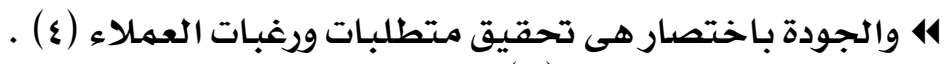

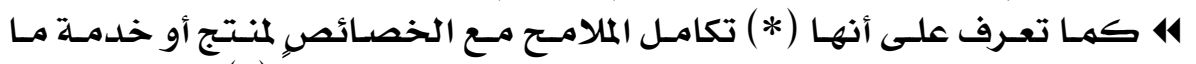

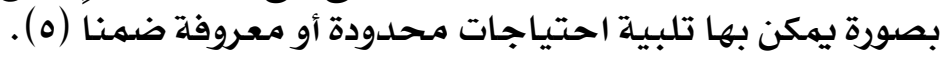

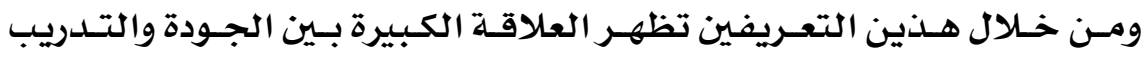

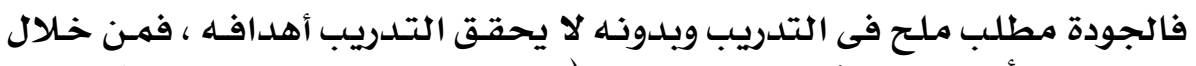

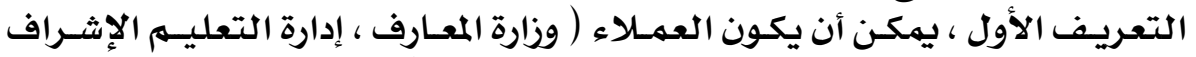

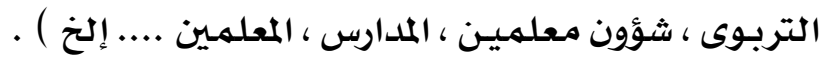

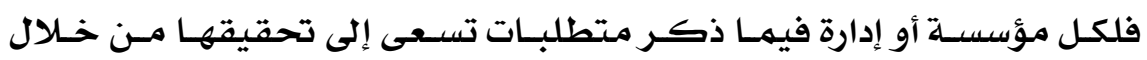

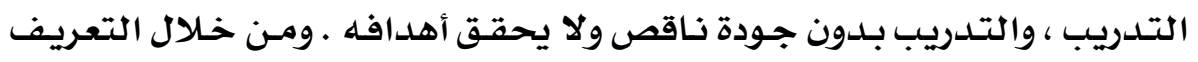

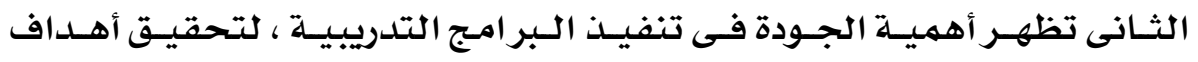

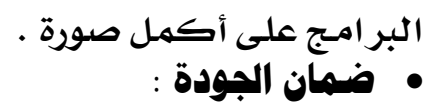

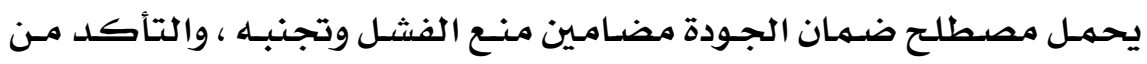

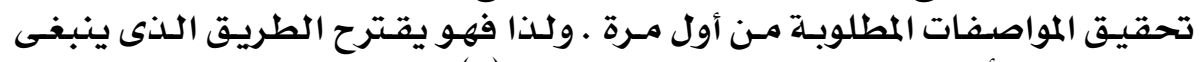

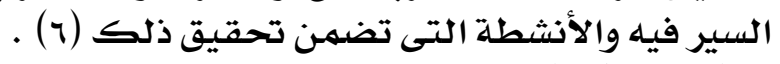

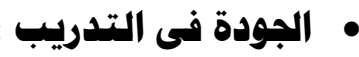

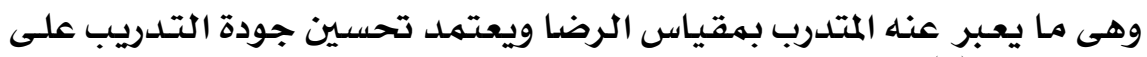

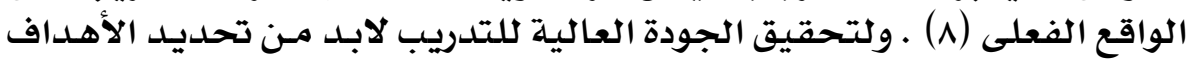

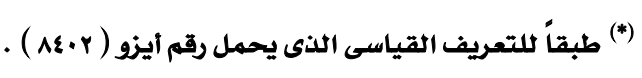

\section{\&71}




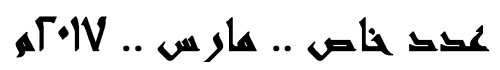

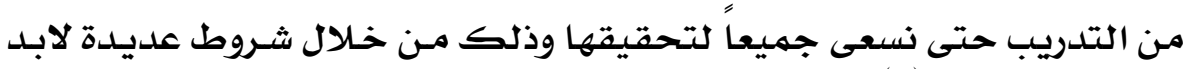

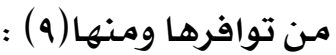
414 الشعور بالرضا لكالالتحاق بالتدريب .

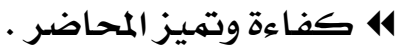

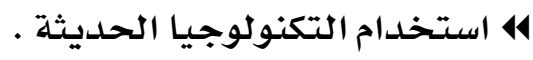

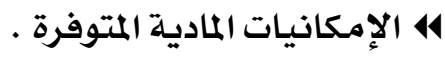
4 له تنويع أساليب التدريب ـ [ حلقات ، دروس عمل ، تقارير ، ... إلخ ] .

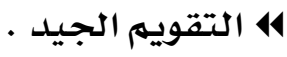

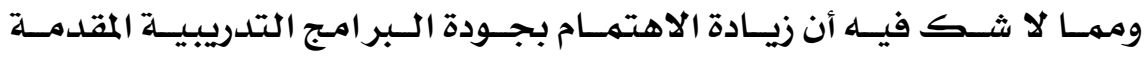

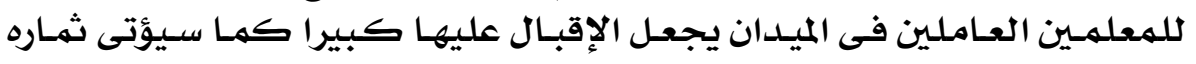

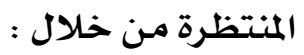

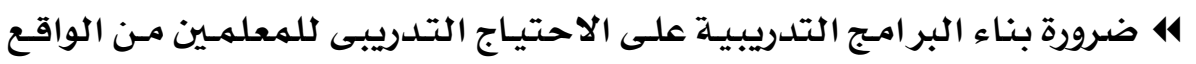

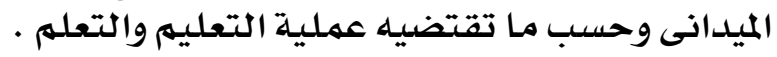

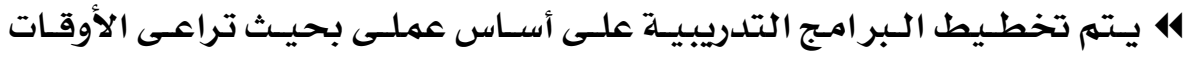

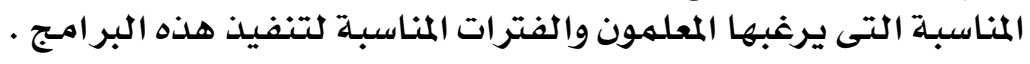

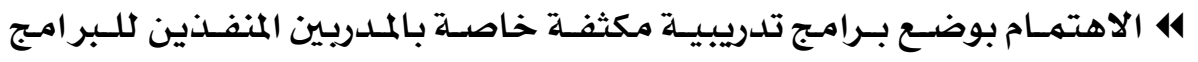

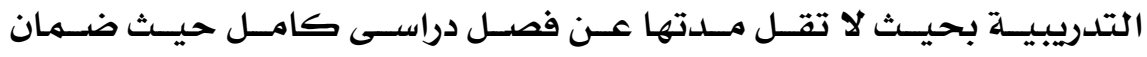

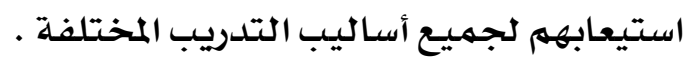

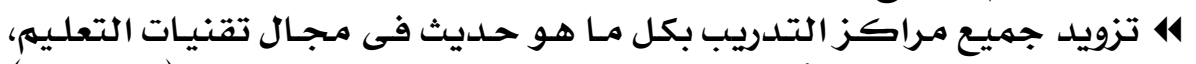

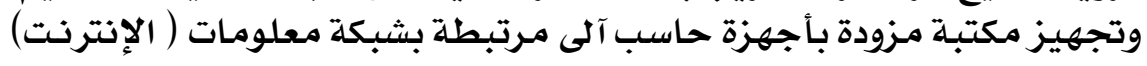

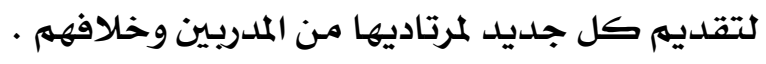

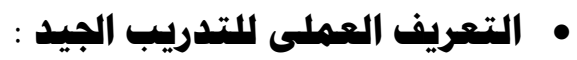

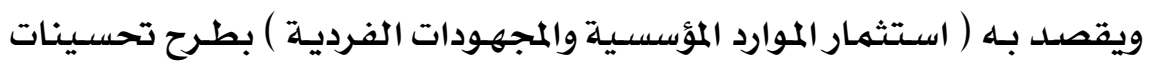

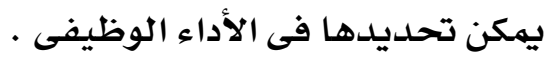

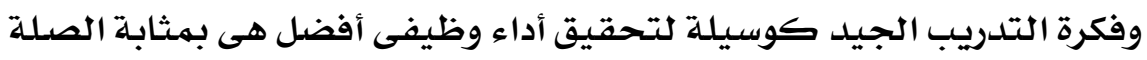

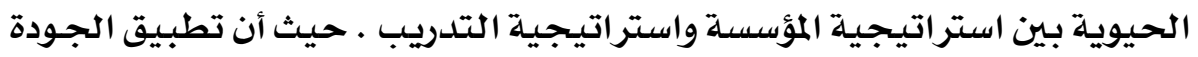

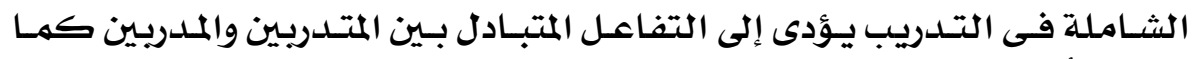

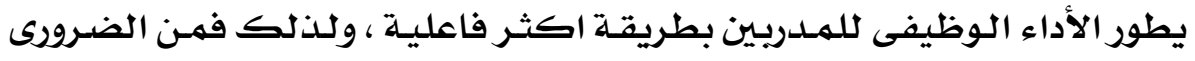

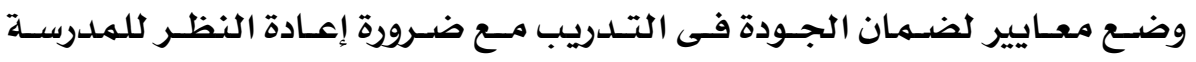
كموقع للتعليم والتدريب ل

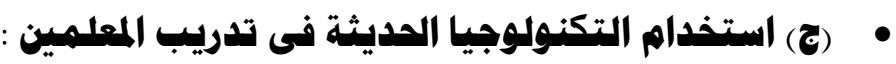

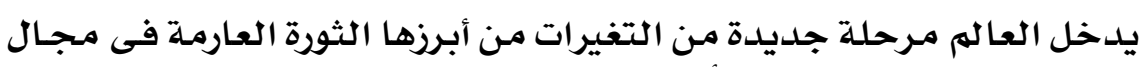

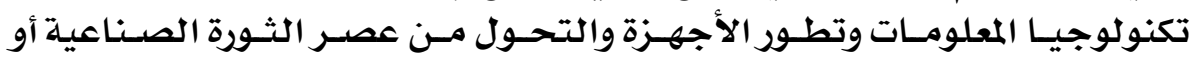

\section{$\varepsilon 7 Y$}

\section{أوراق عهل وبموث المؤتير الدولي الأول لمركز تنسية قدرات أعضاء هيئة}

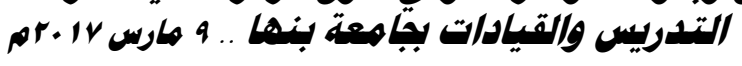




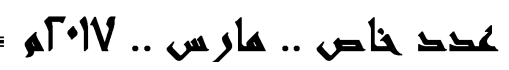

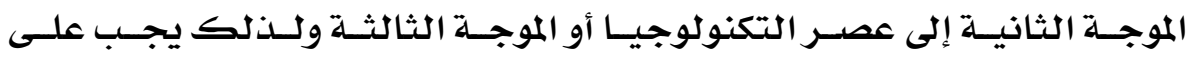

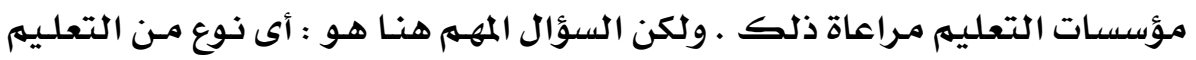
تتطلبه مجتمعات القرن الحادى والعشرين في ظل ثورة المعلومات المات والتكنولوجيا

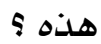

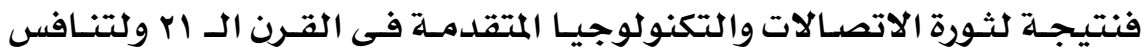

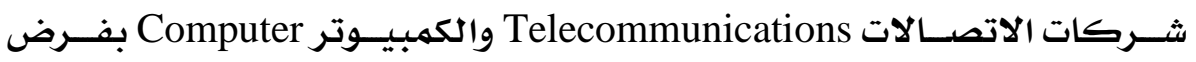

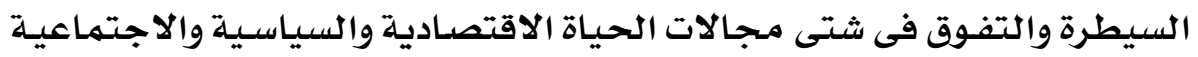

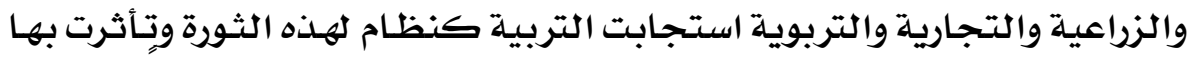

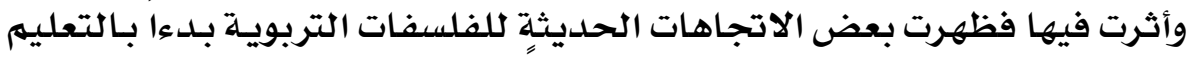

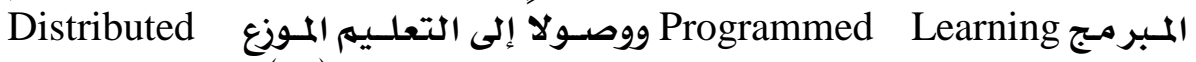

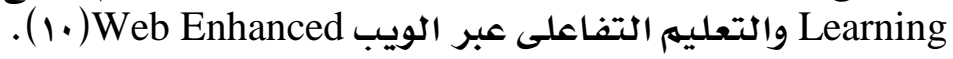

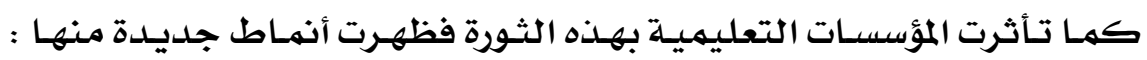

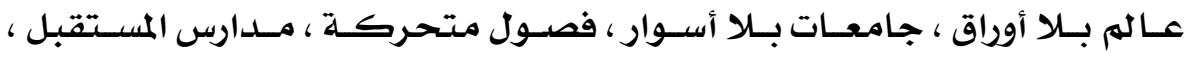

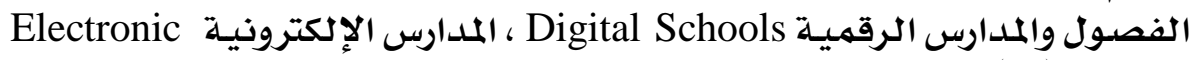
.(11)Schools

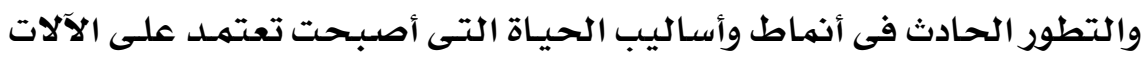

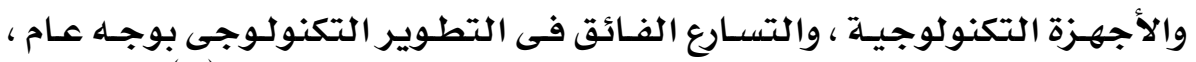

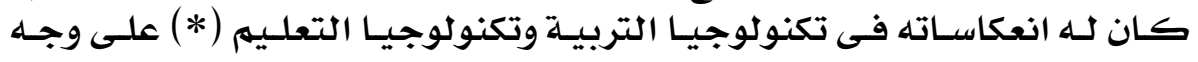

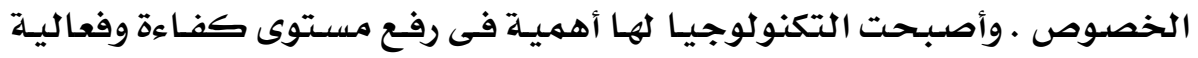

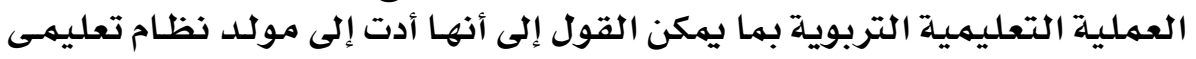

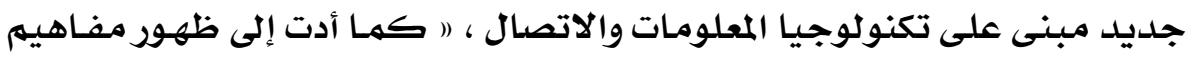

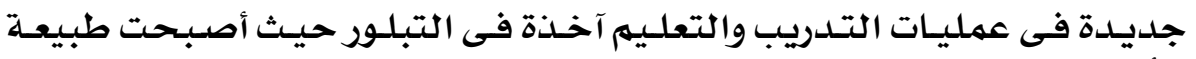

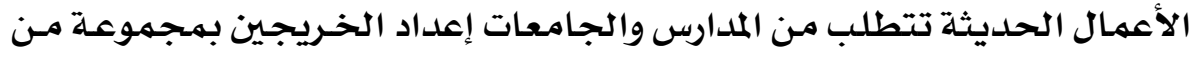

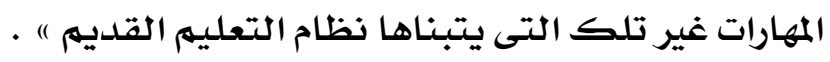

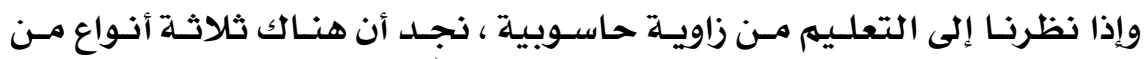

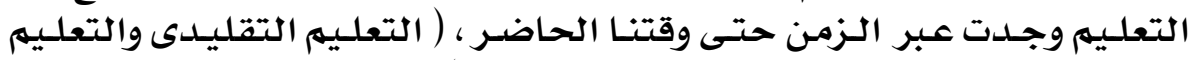

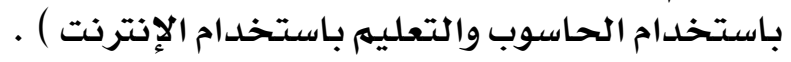
وبالحديث عن التعليهم التقليـدى نجـد أنه يرتكز على ثلاثة محساور أساسيـة ،

" تكنولوجيا التعليم "EDUCATIONAL-TECHNOLOGY "

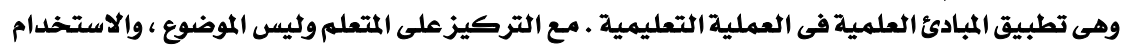
الواسع للوسائل السمعية والبصرية ومعاملية العمل التعلم وألتعليم المبرميج والآلات التعليمية.

\section{$\varepsilon 7 \%$}




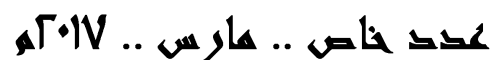

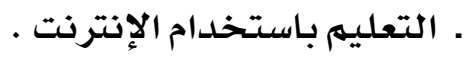

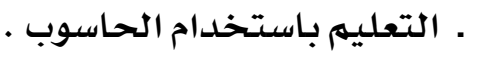

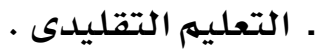

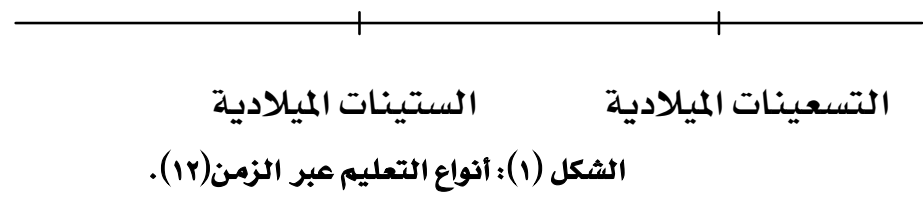

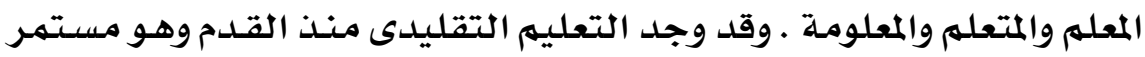

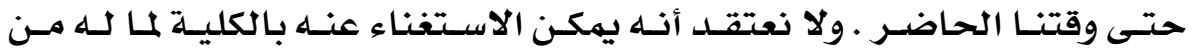

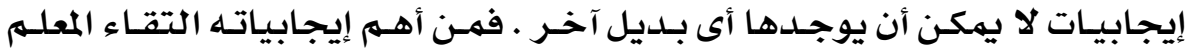

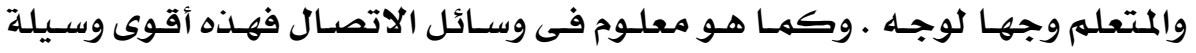

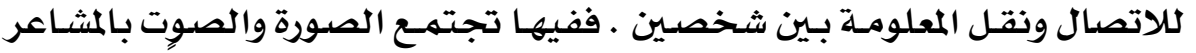

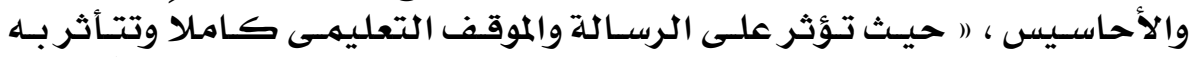

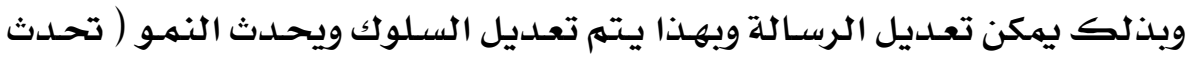

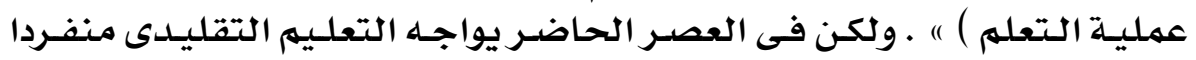

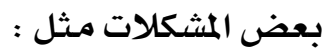

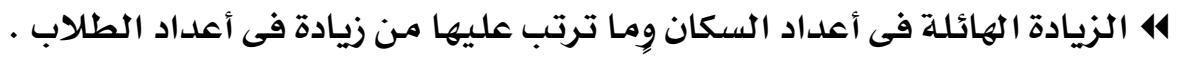

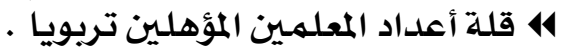

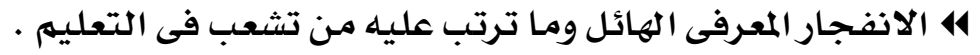

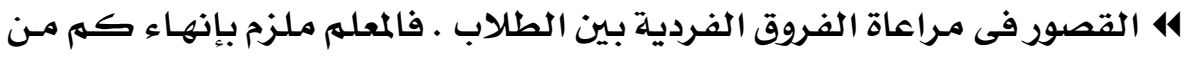

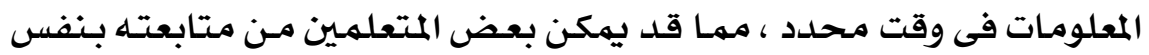

$$
\text { السرعة (ir) }
$$

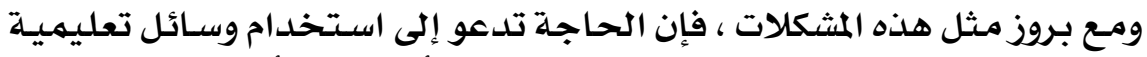

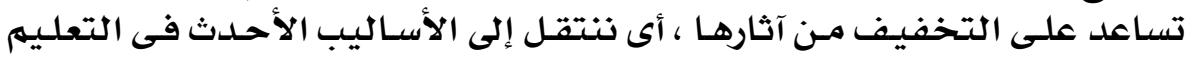

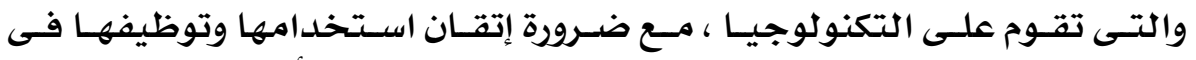

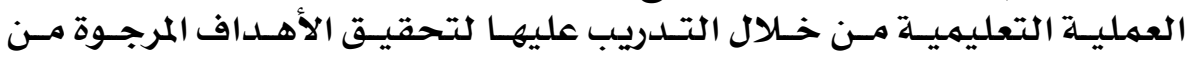
تطبيقها على الوجه الأكمل.

\section{$\varepsilon 7 \varepsilon$}




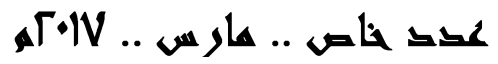

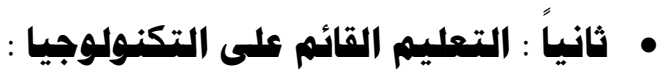

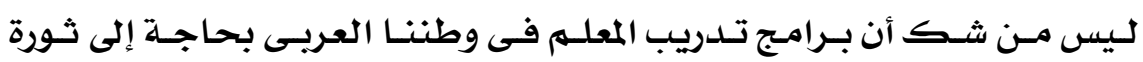

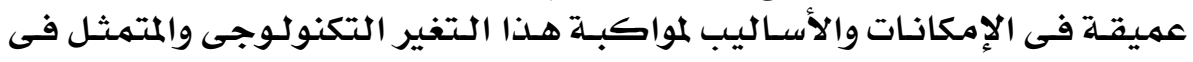

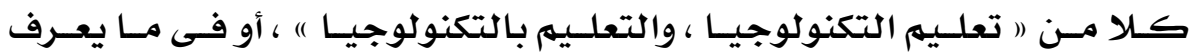

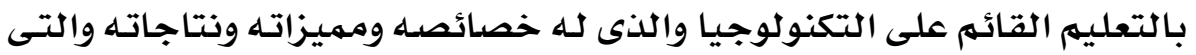
توضحها الدراسة الحالية كالتالى :

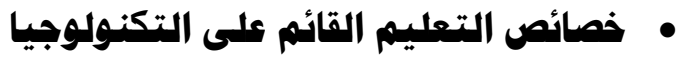

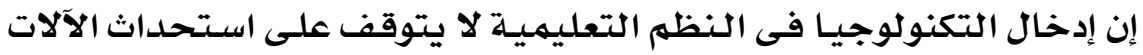

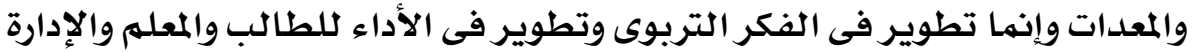

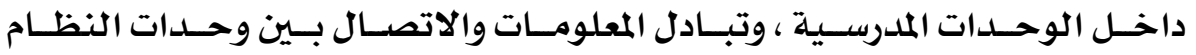

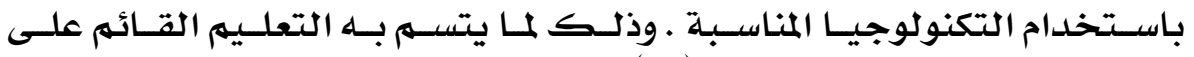

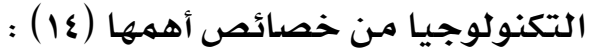

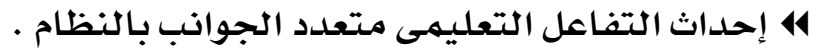

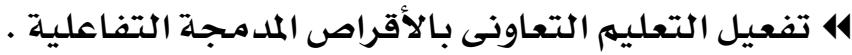

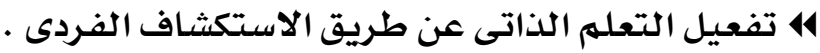

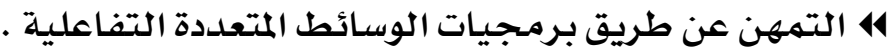

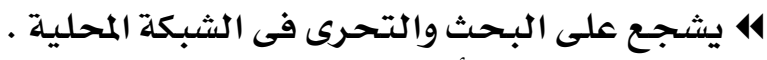

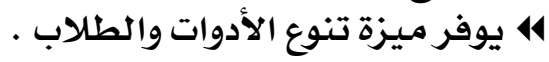

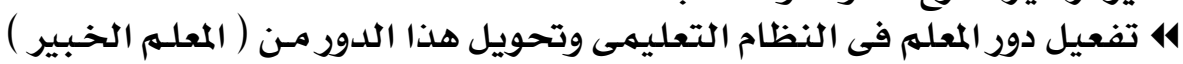

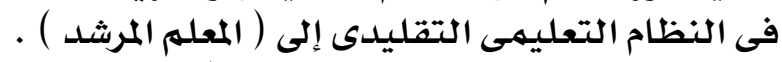

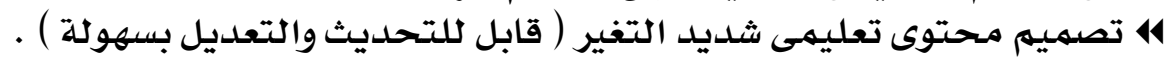

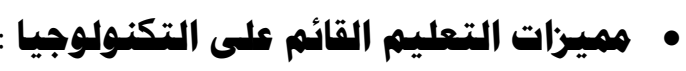

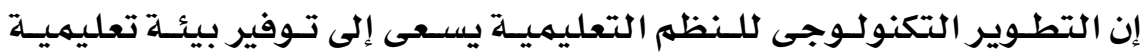

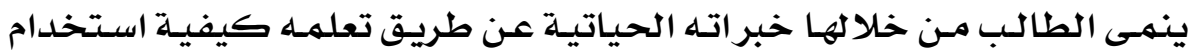

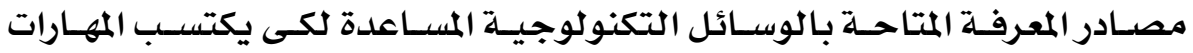

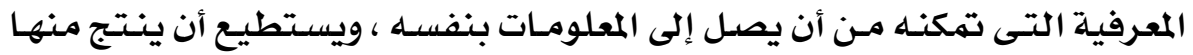

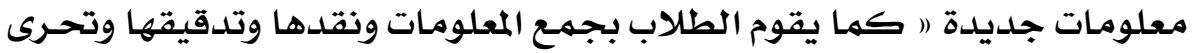

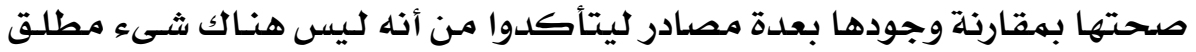

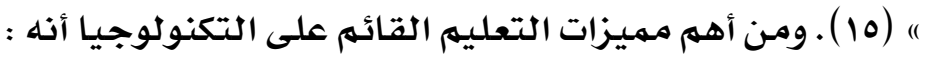

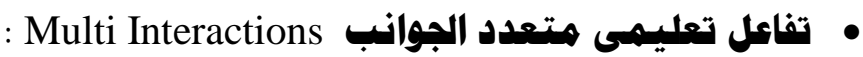

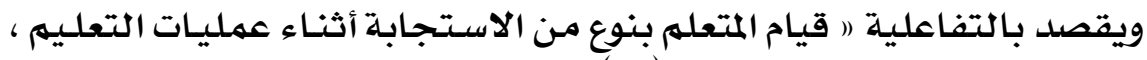

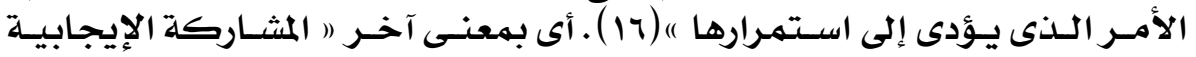

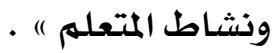

\section{$\varepsilon 70$}




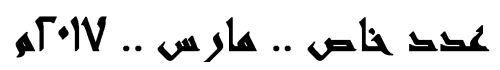

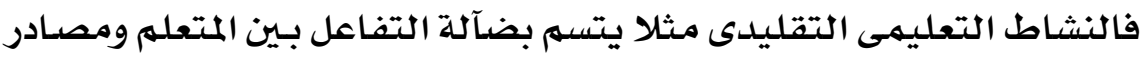

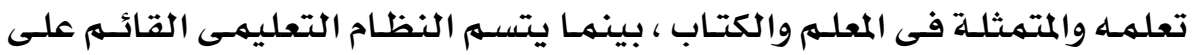

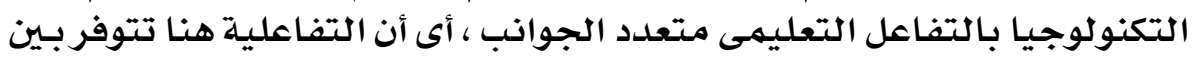

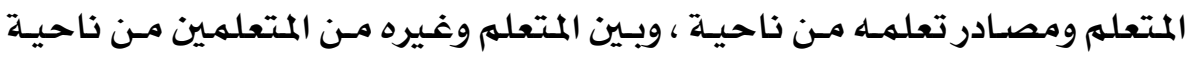

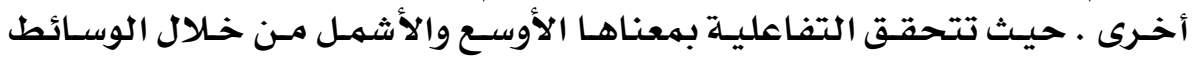

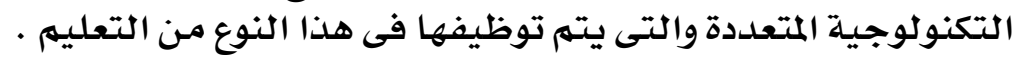

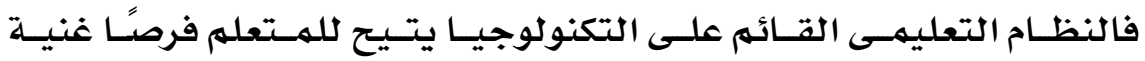

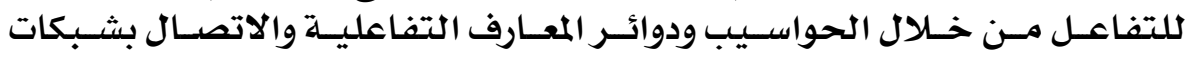

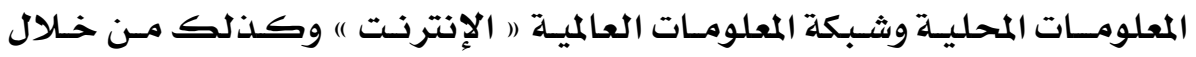

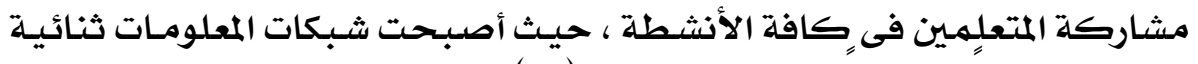

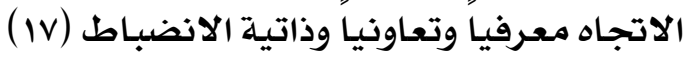

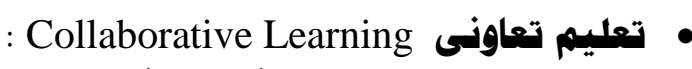

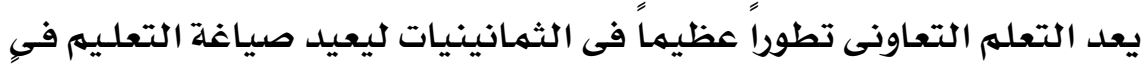

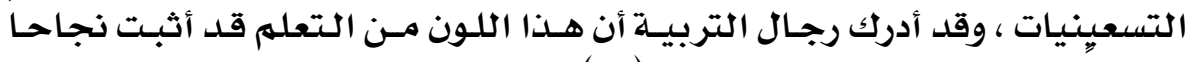

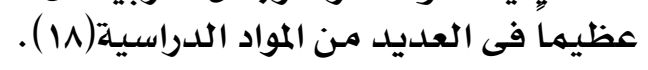

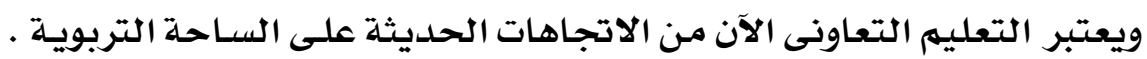

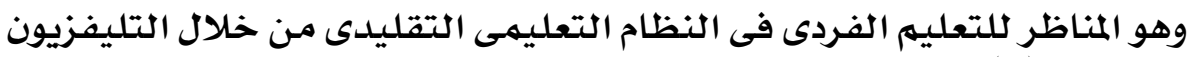

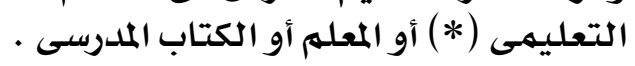

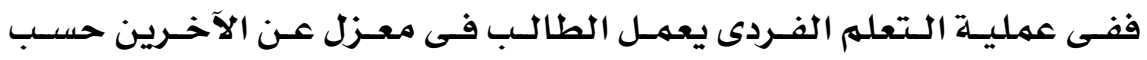

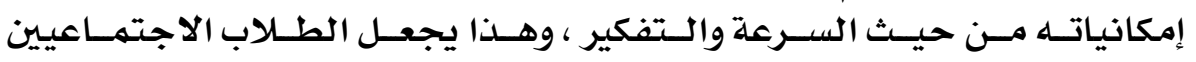

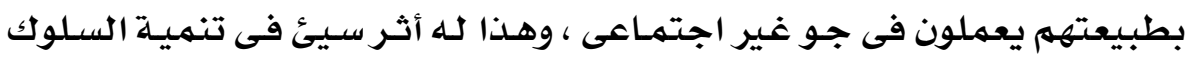

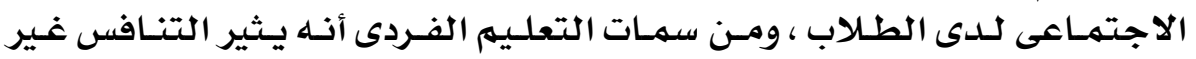

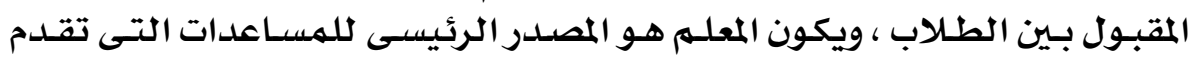

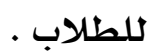

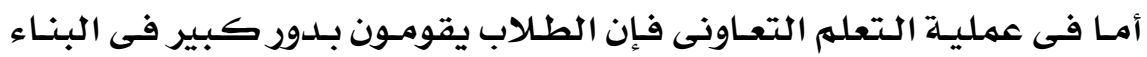

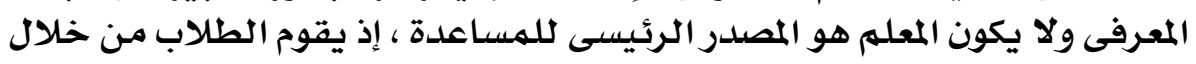

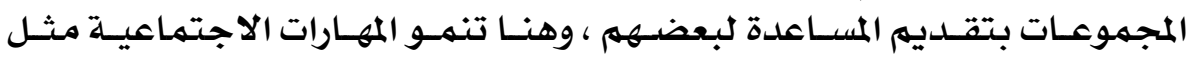

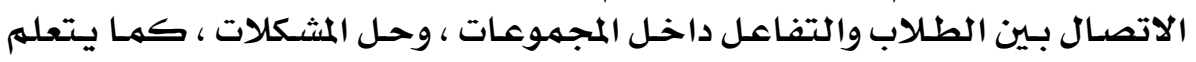

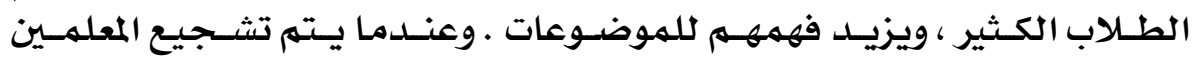

") " التليفزيون التعليمى "EDUCATIONAL-TELEVISOSION"

هو إذاعة غير تجارية حيث لا تذيع الإعلانات وتقوم ببث برامج تعليمية ثقافية وترويحية وأخرى متخصصة للمقرات الدراسية (r) .

\section{$\varepsilon 74$}




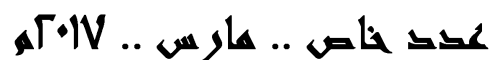

والطلاب على العمل بصورة تعاونية فإن ذلك يكون لـه أثر إيجابى على البيئـة

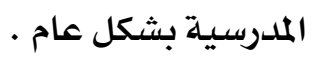

\section{• Interdisciplinary تعليم بيئى متداخل}

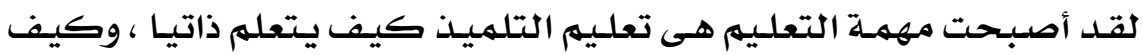

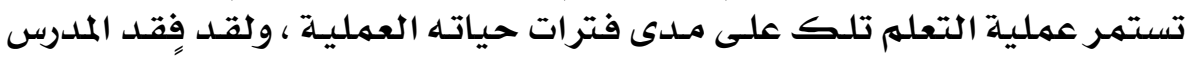

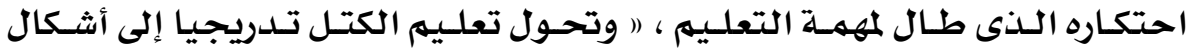

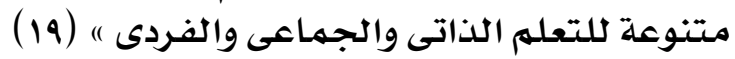

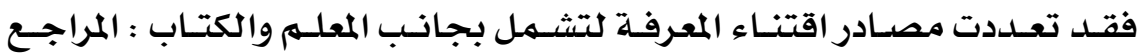

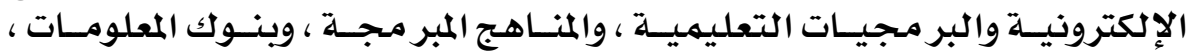

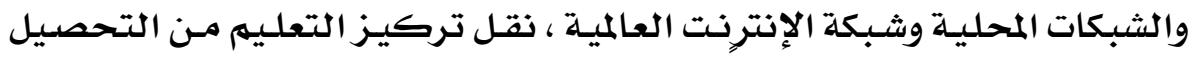

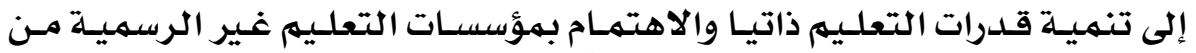

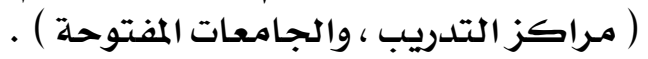

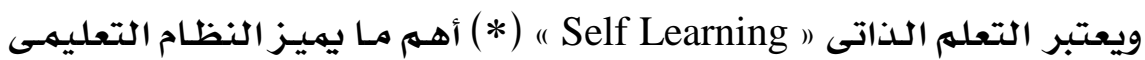

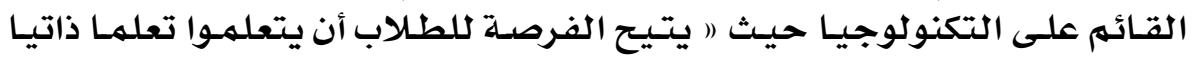

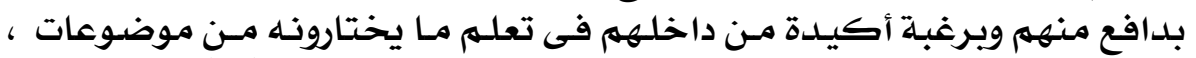

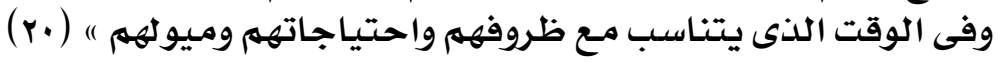

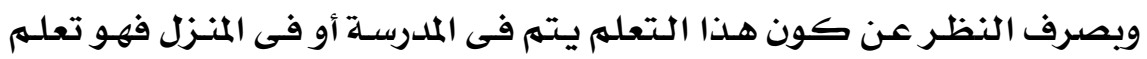

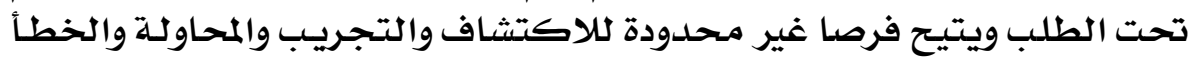

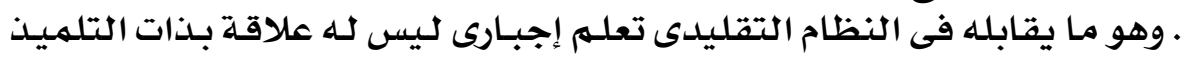

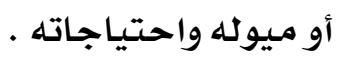

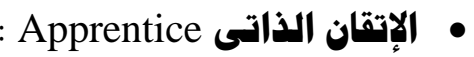

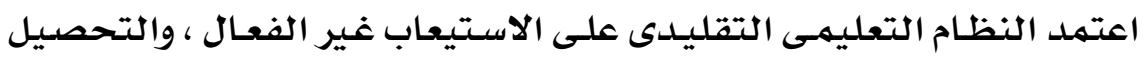

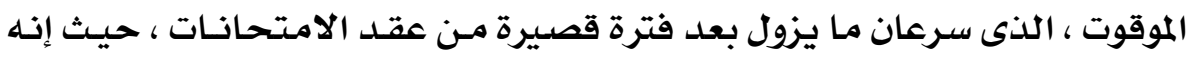

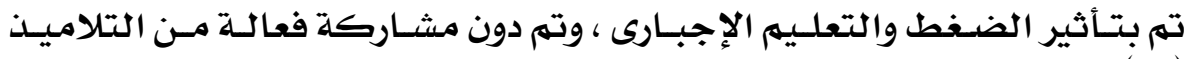

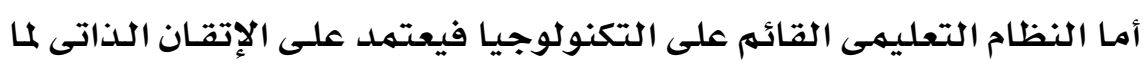

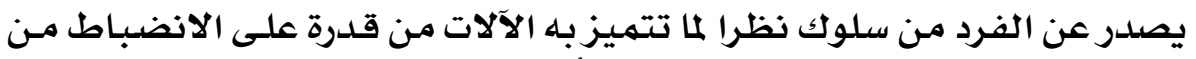

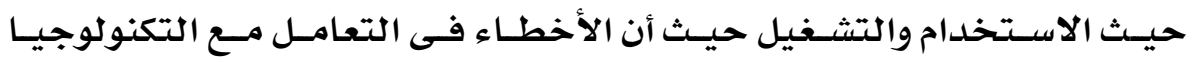

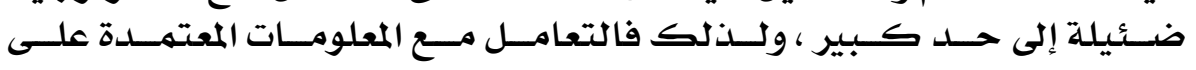

: "SELF-LERNING" التعلم الناتى (*)

هو التعليم الذيى يقوم به الدارس عن طريق بواعثه الخاصة ويدون تدخل المدرس ، ويستخدم الفرد فيه من تلقاء ثفسه الكتب أو الاكلات التعليمية او غيرها من الوسائل ، كما يختار وبنفسه نوع ومدى دراسته ويتقدم فيها وفتاً لمقدرته .

\section{$\varepsilon 7 \vee$}




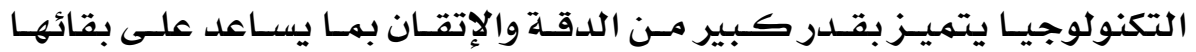

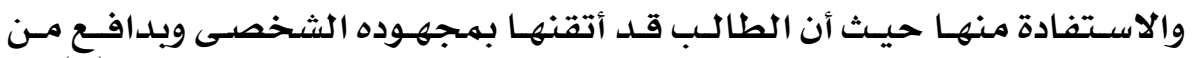

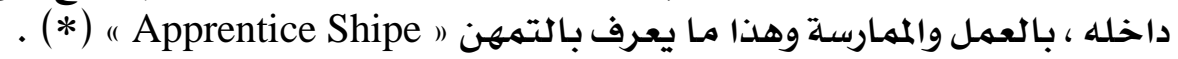

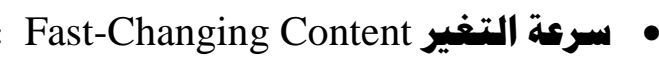

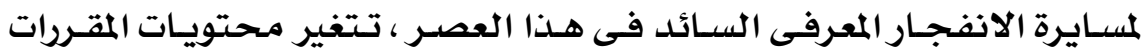

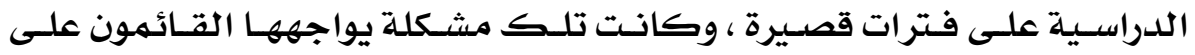

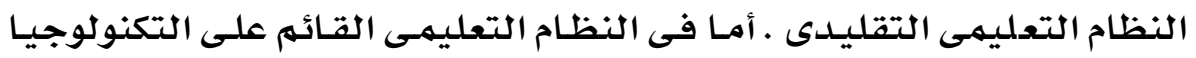

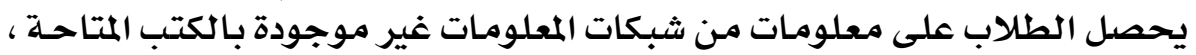

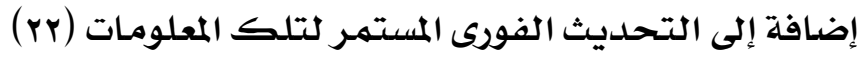

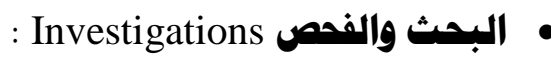

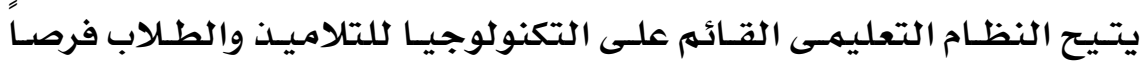

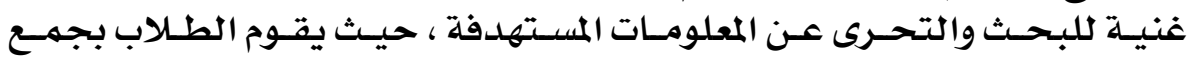

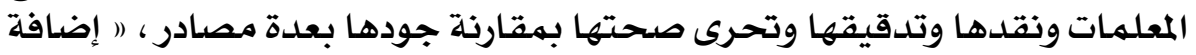

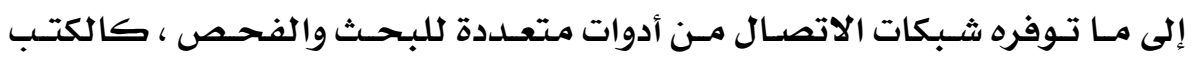

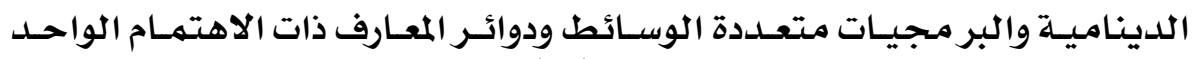

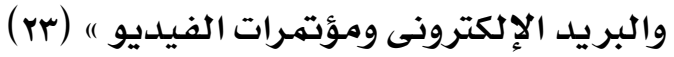

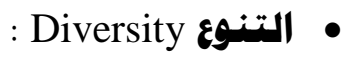

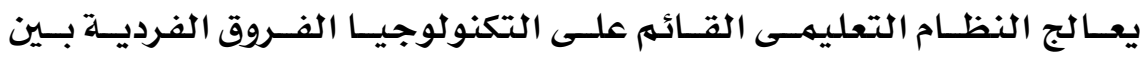

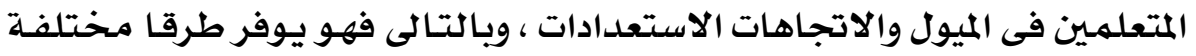

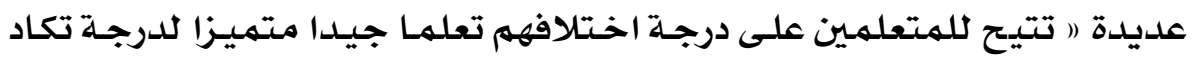

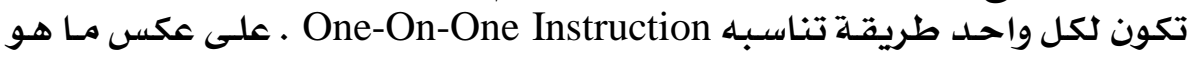

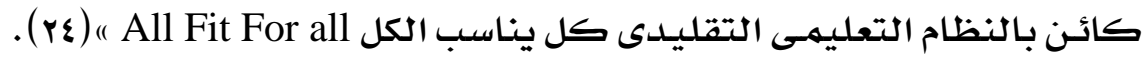

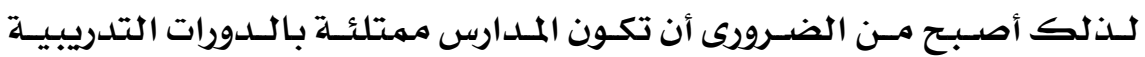

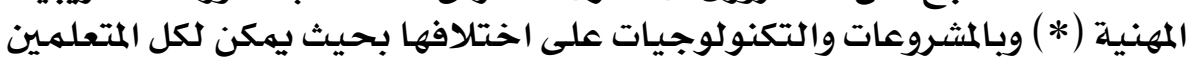

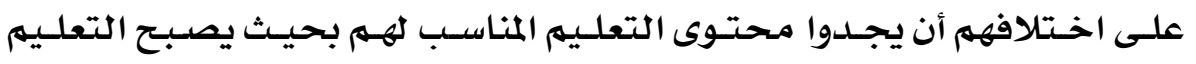

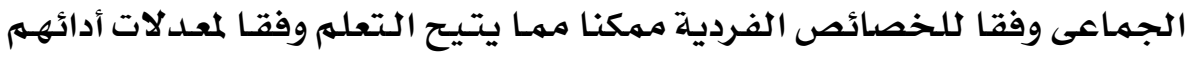

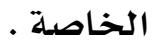

: "Apprentice Shipe" التمهن (*) ويقصد به تهيئة الموقف التعليمى وتنظيمه على النحو الذى يستثير دوافع التلميذ إلى التعلم ويزيد من قدراته على الاعتماد على نفسه متفاعلا مع مصادر الخبرة المتاحة له بما يعينه ملى اكتساب المعلومات والمهارات المطلوبة وزيد من قدرته على تقويم مدى تقدمه نحو تهقيق الهدافيه. : "VOCATIONAL-TRANING" التدريب المهنى (*) 


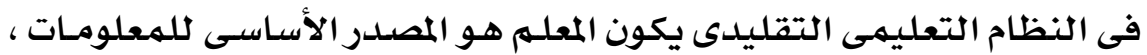

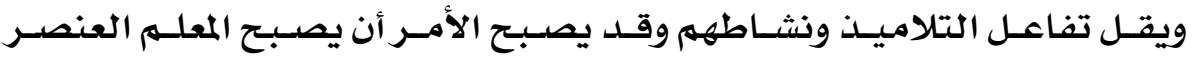

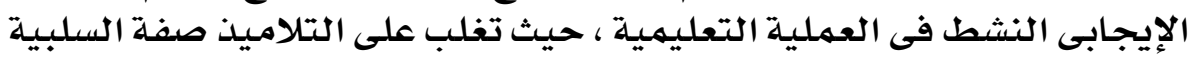

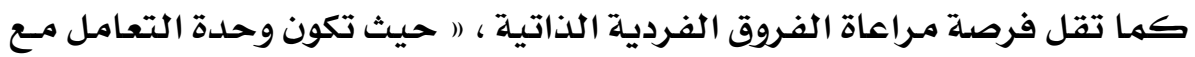

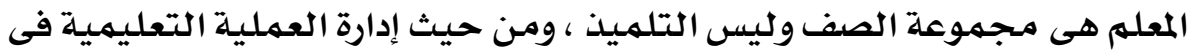

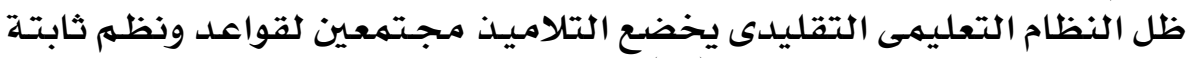

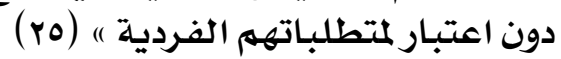

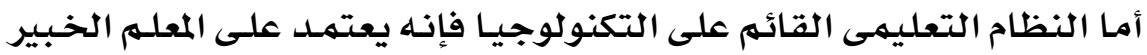

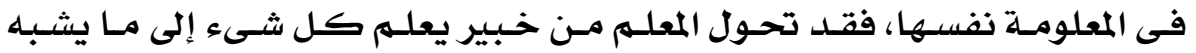

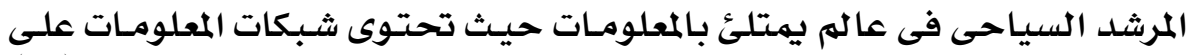

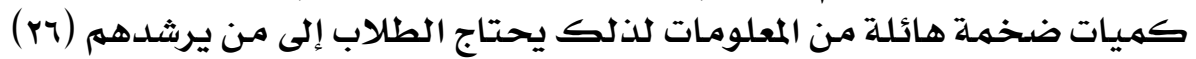

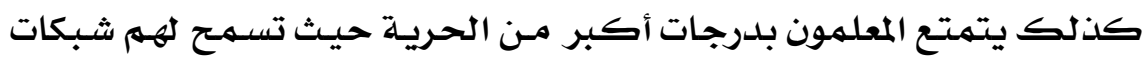

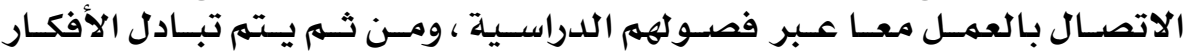

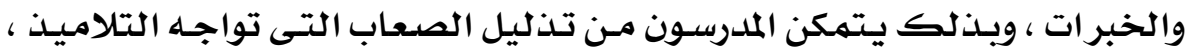

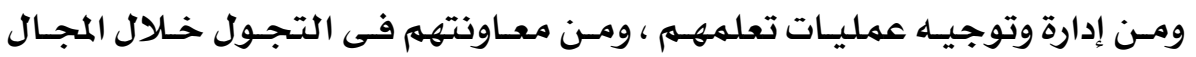

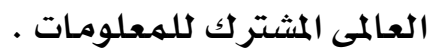

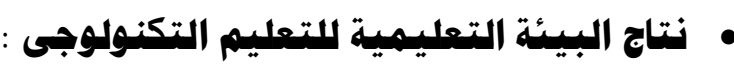

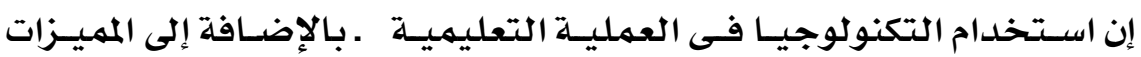

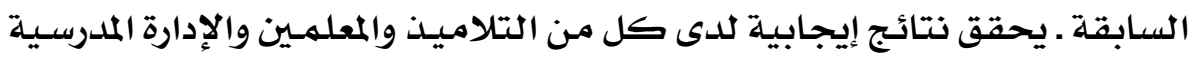

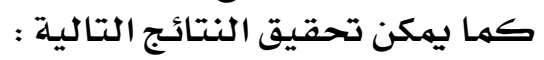

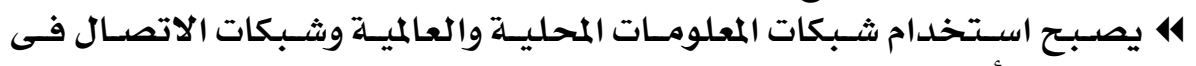

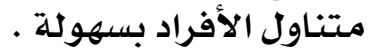

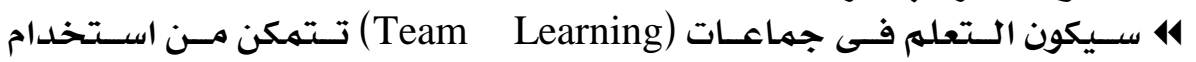

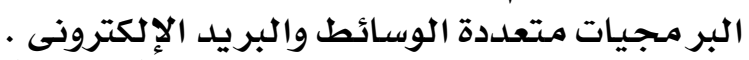

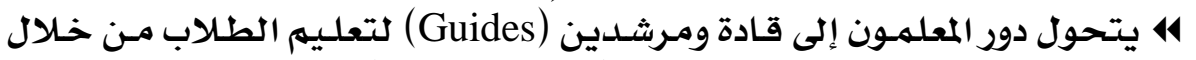

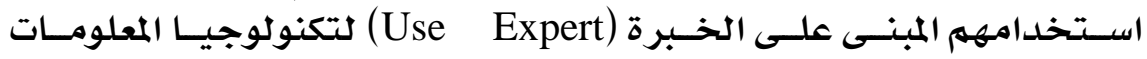

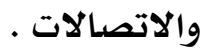

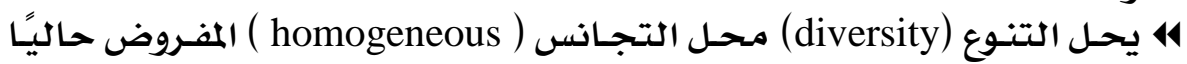

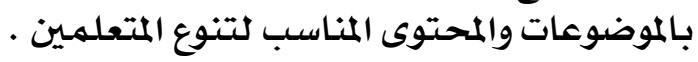

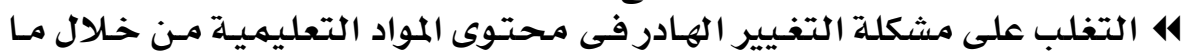

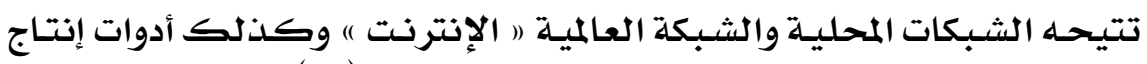

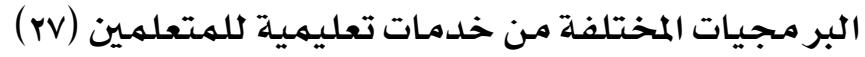

\section{$\varepsilon 79$}




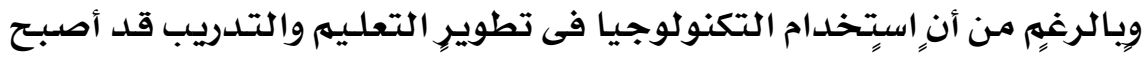

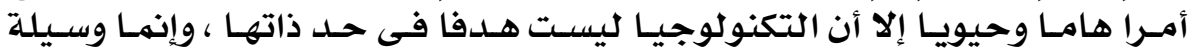

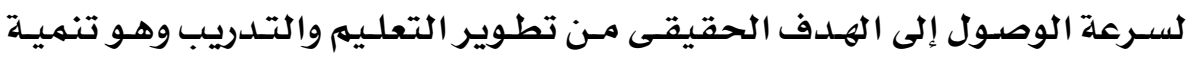

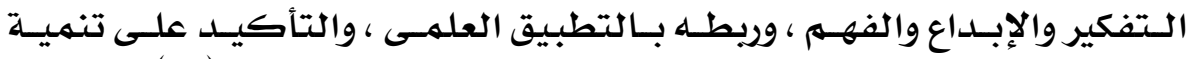

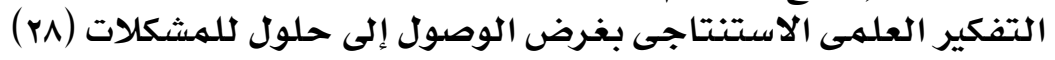

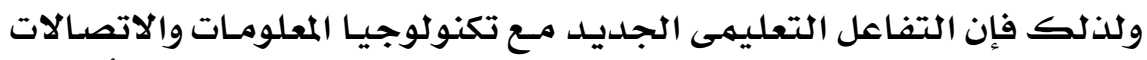

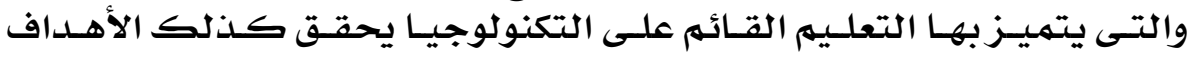

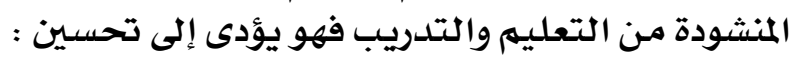

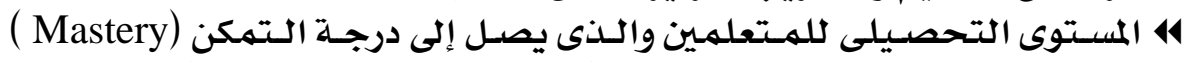

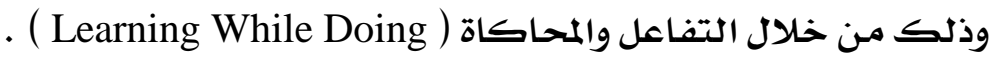

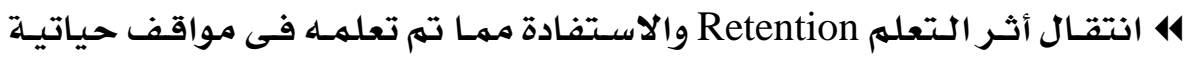

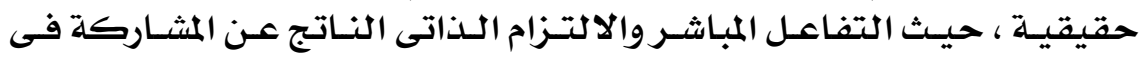

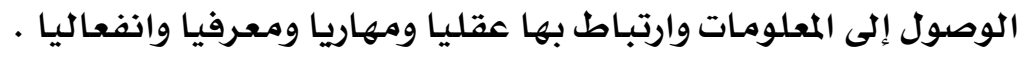

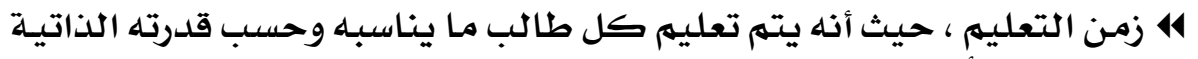

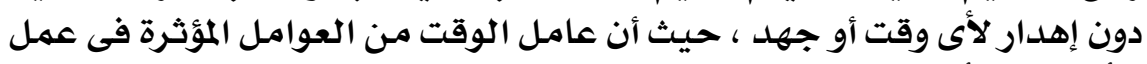

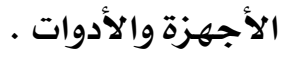

4 اتجاهـات الطلاب والمعلمـين نحو التعليهم مـن ناحيـة ونحو المجتهـع مـن ناحيـة

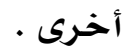

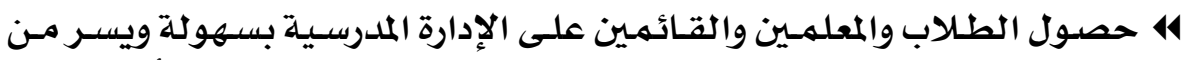

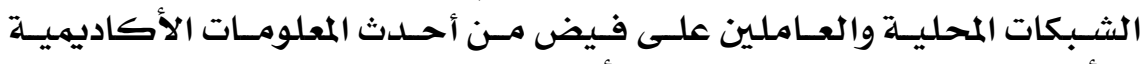

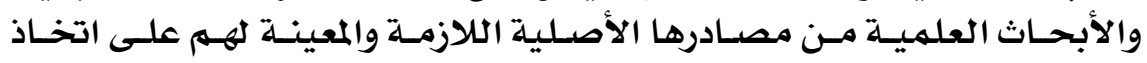

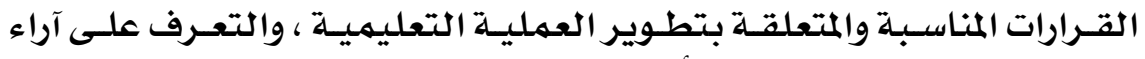

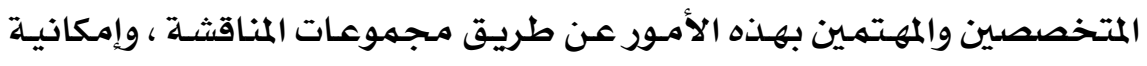

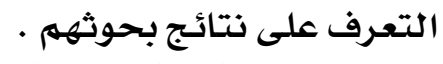

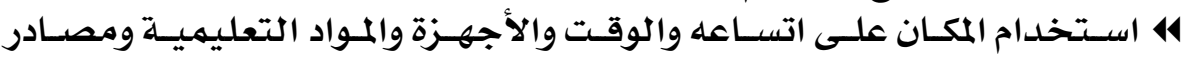

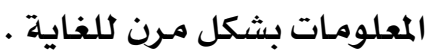

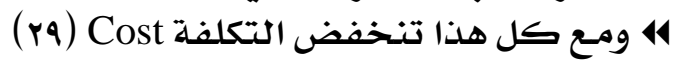

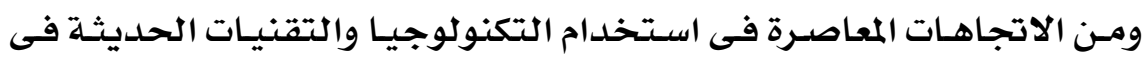

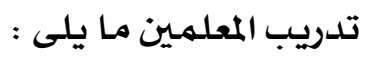

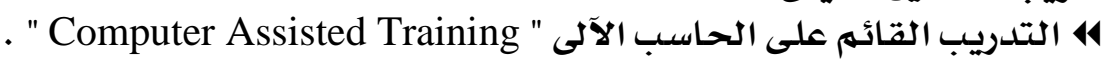

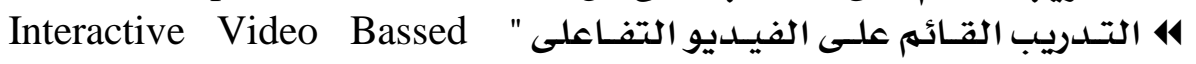
" Training 14 التدريب باستخدام منحنى الوسائط المتعددة " Multi-media Approach to in-service Teacher Training " 4

\section{$\varepsilon V$.}




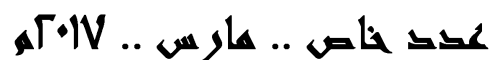

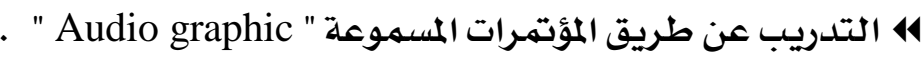

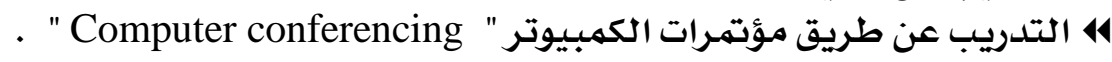

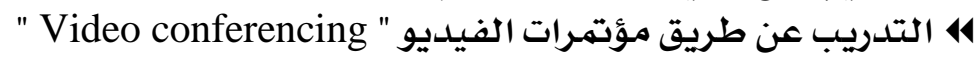

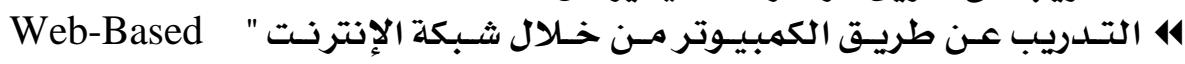
" Training

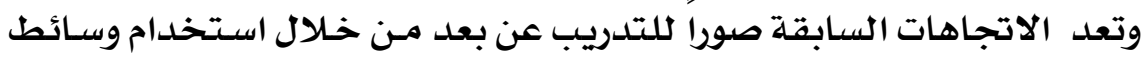

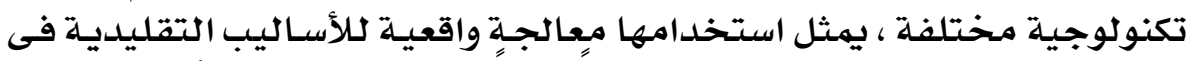

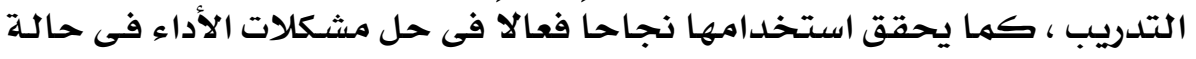

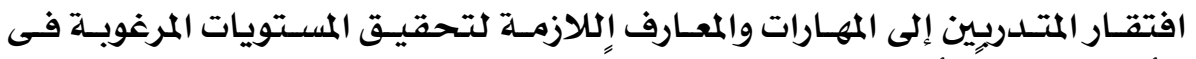

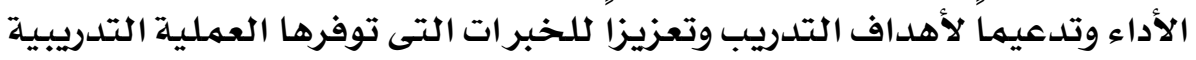

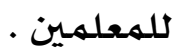

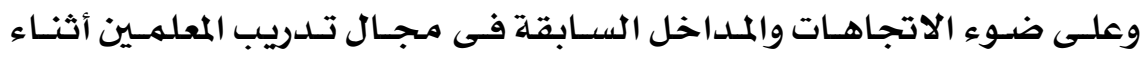

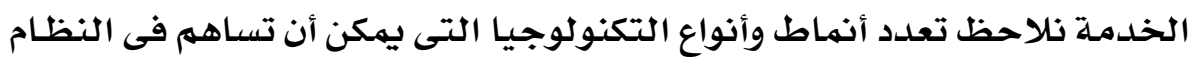

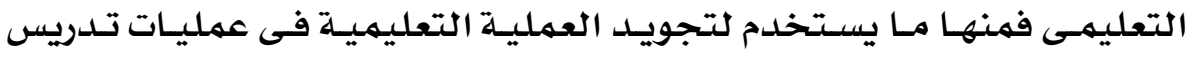

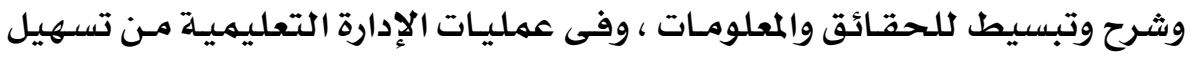

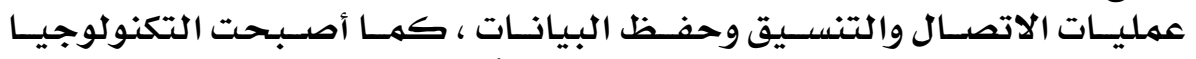

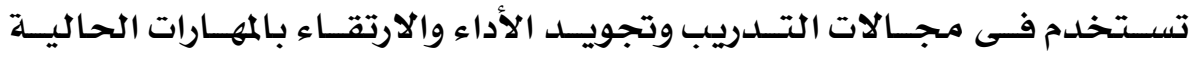

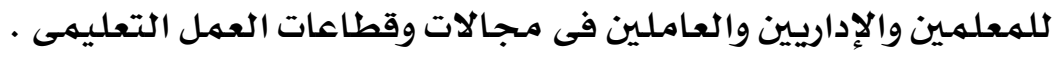

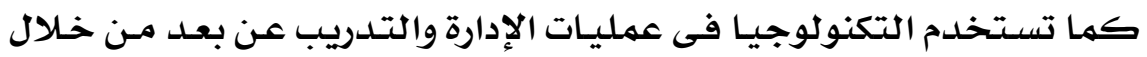

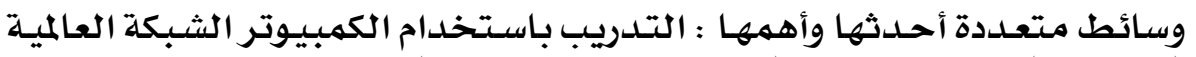

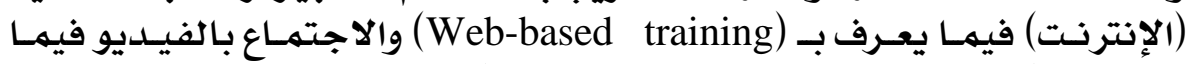

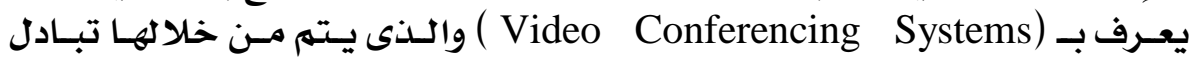

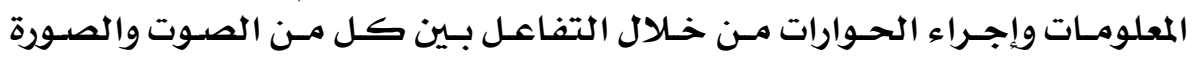

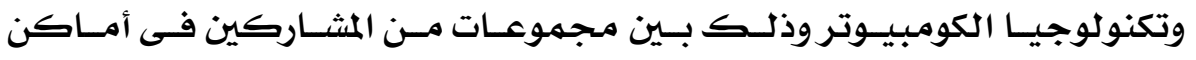

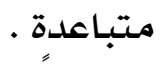

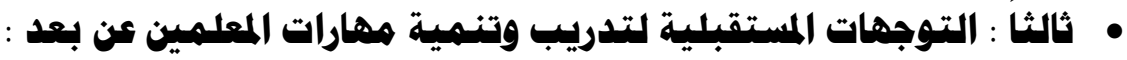

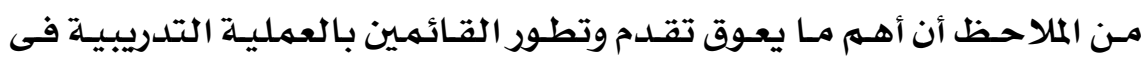

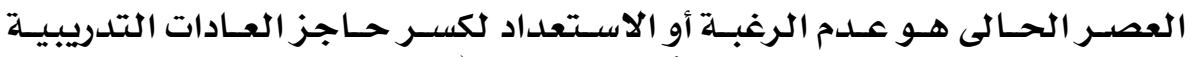

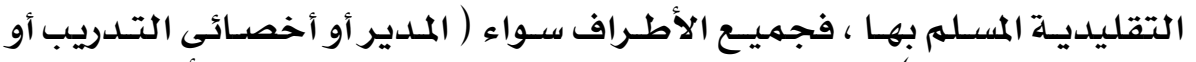

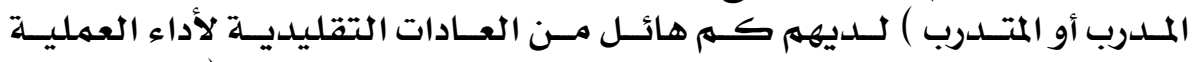

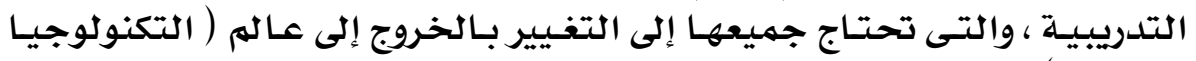

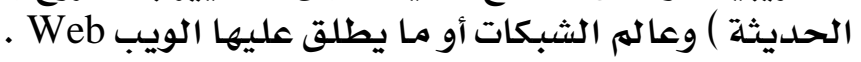

\section{$\varepsilon \vee 1$}




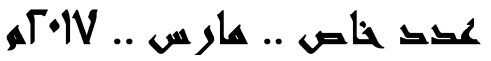

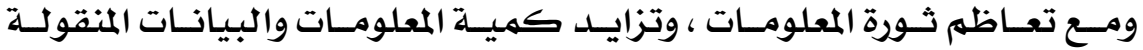

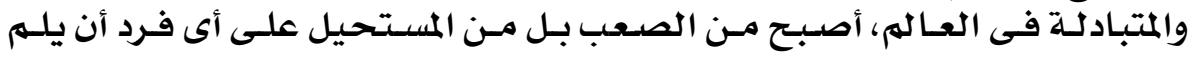

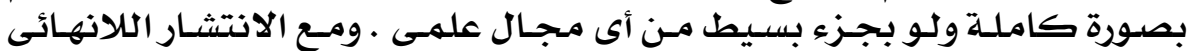

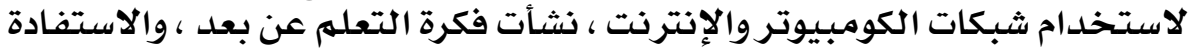

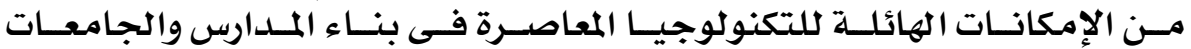

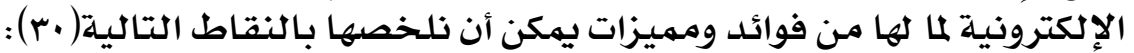

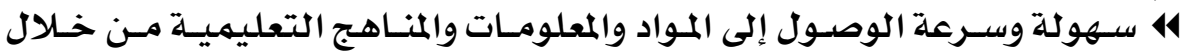

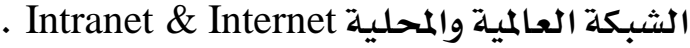

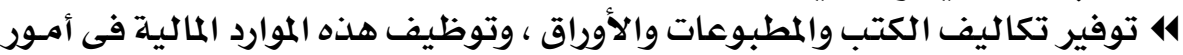

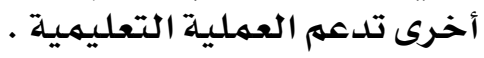

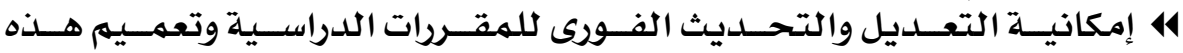

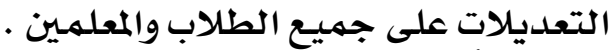

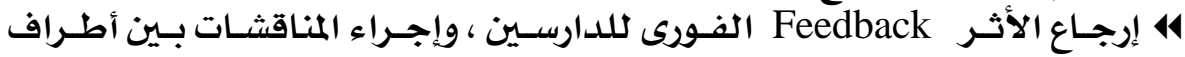

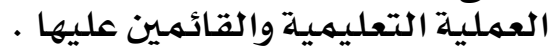

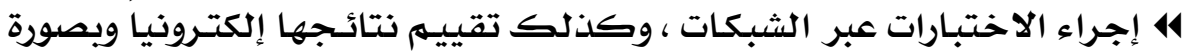
تلقائية . الاءحت

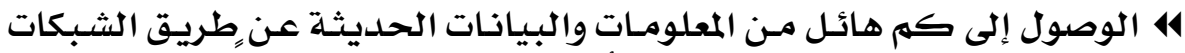

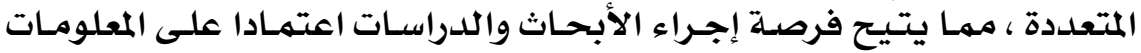

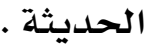

( أ ) التوجهات المستقبلية لتمديث براهج تدريب المهلمين عن بعد (الم) :

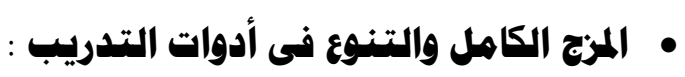

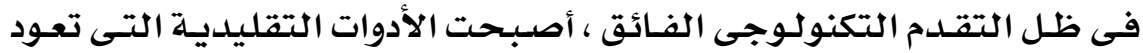

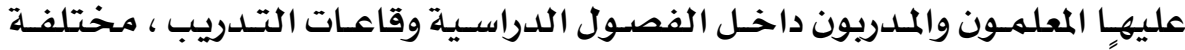

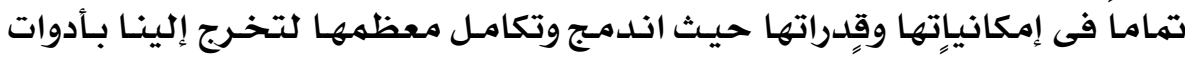

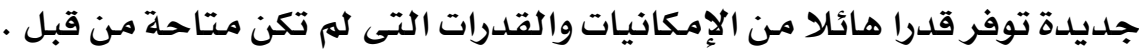

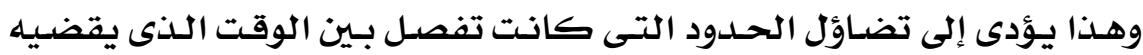

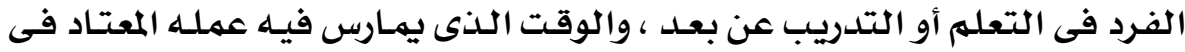

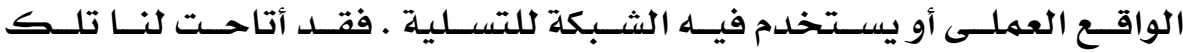

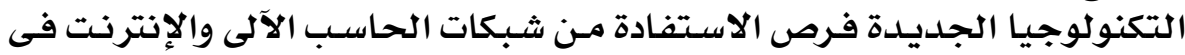

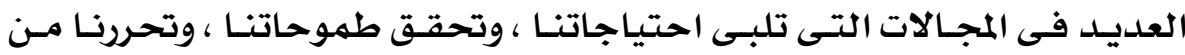

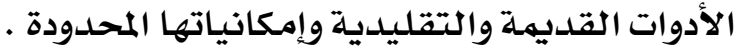

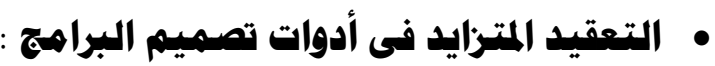

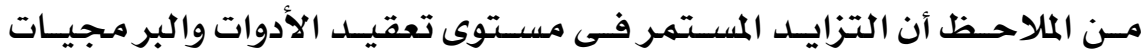

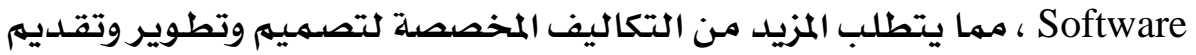

\section{$\varepsilon \vee Y$}




\section{لحق خاص .. عار س .. VI. مa}

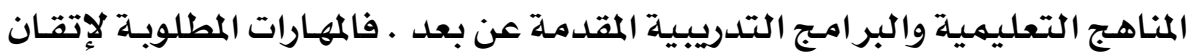

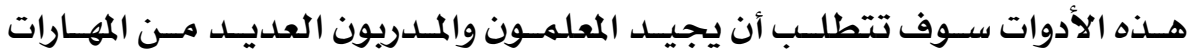

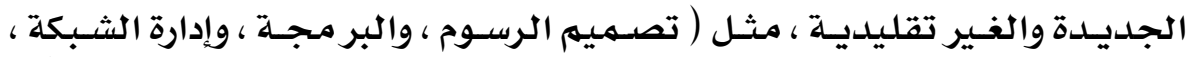

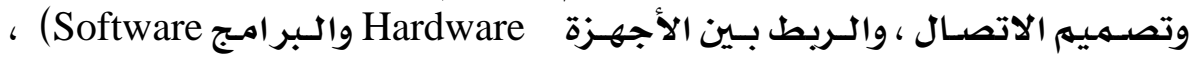

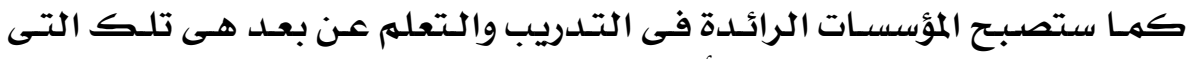

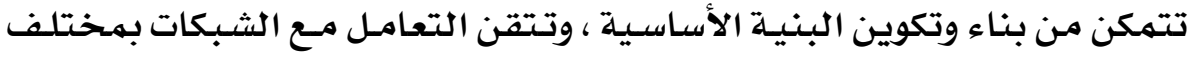

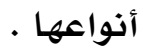

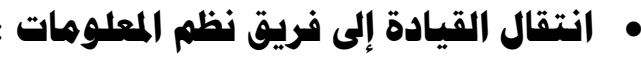

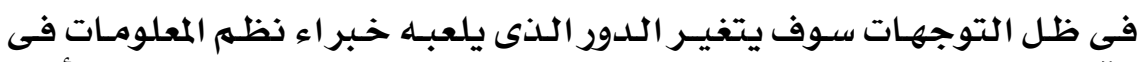

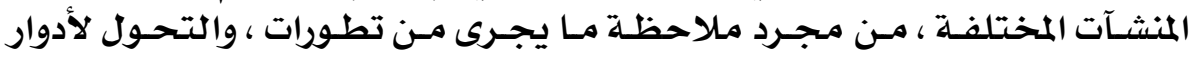

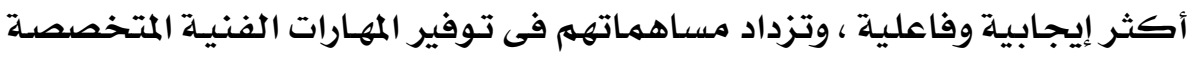

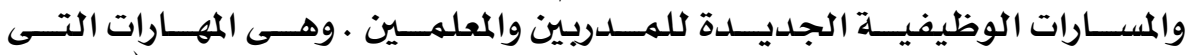

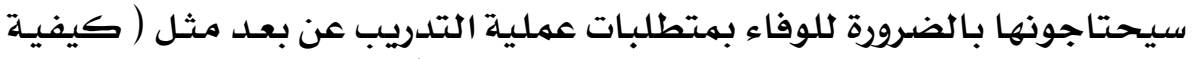

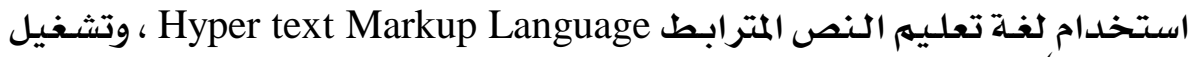
الشبكات ) (استخدات

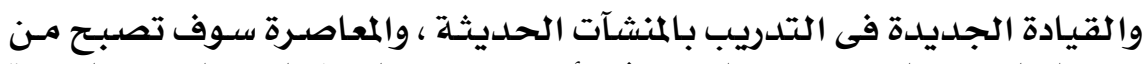

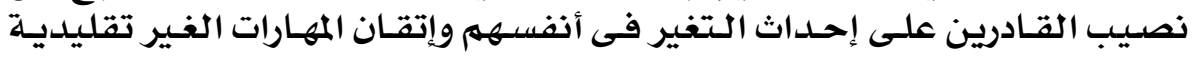

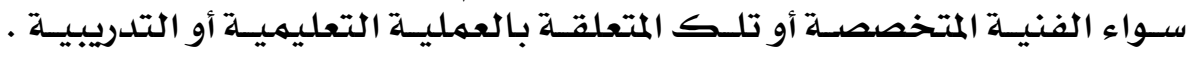

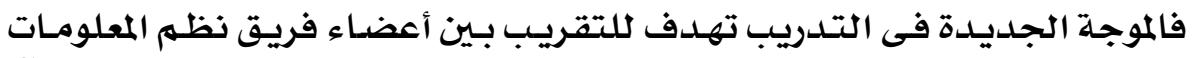

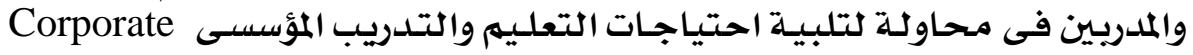
. Training

\section{• تعاظم الاهتهام بمراكز التعلم المؤسسية (المؤسسات التدريبية) :}

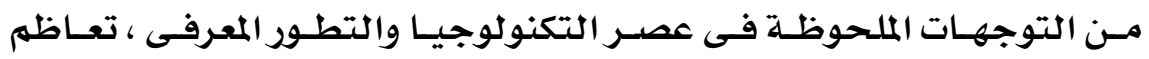

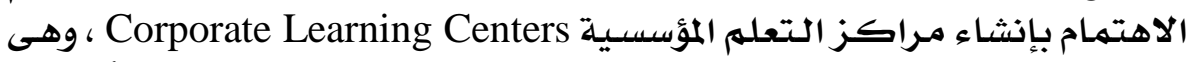

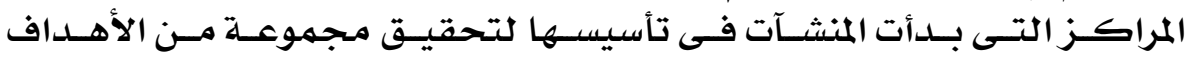

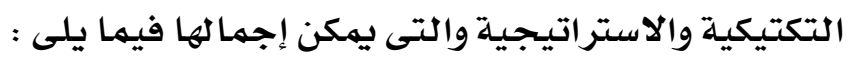

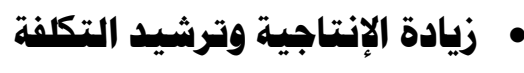

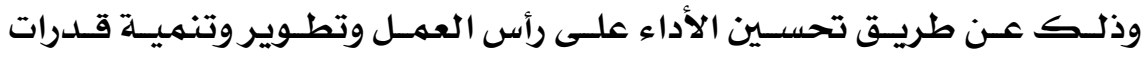

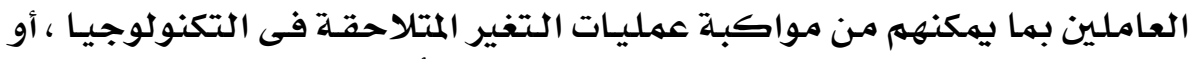

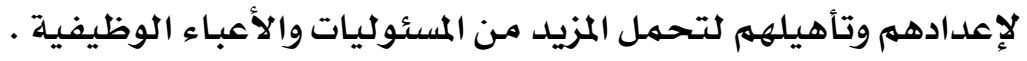

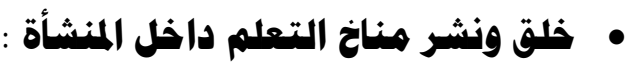

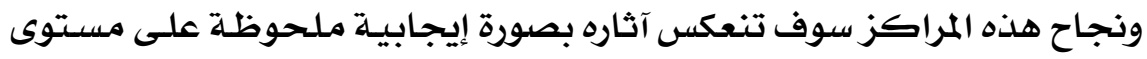

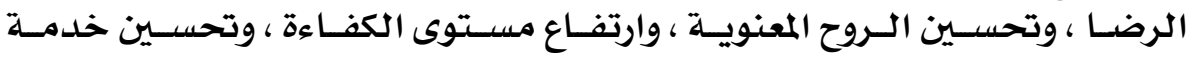

\section{$\varepsilon \vee r$}




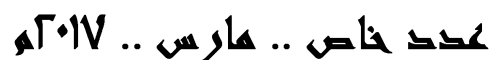

العملاء ، وارتفاع مستوى الجودة ، وتوفير الفرص المتطورة للتعلهم والتدريب أمـام العاملين بالمنشأة . العماع.

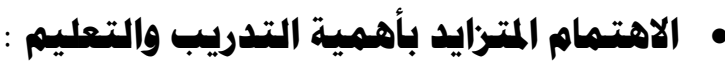

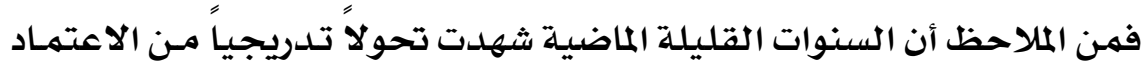

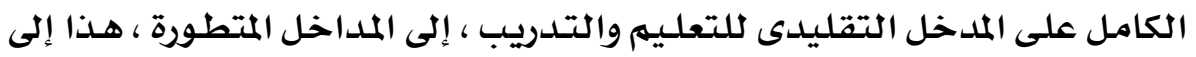

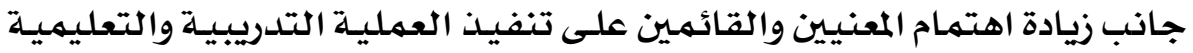

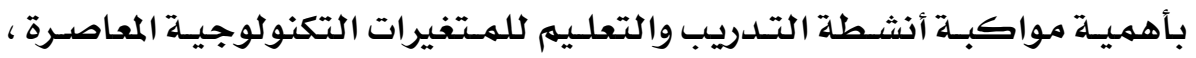

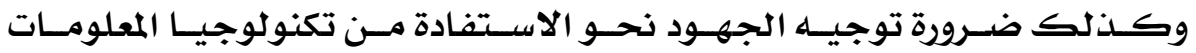

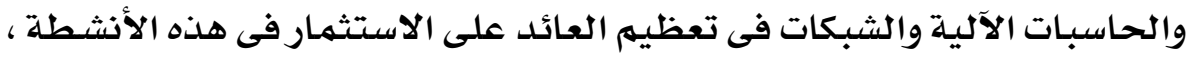

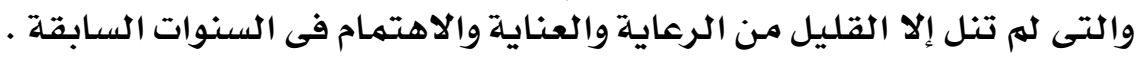

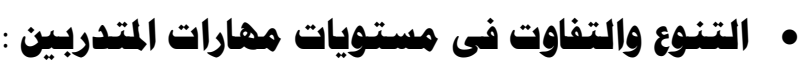

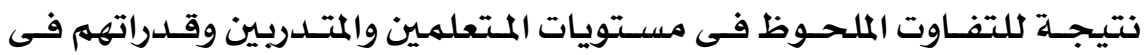

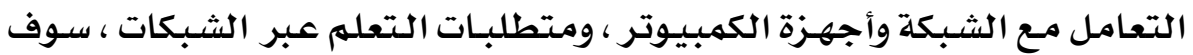

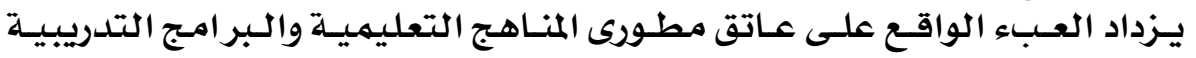

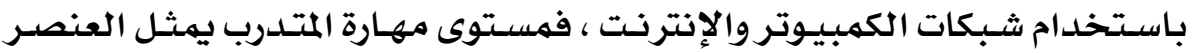

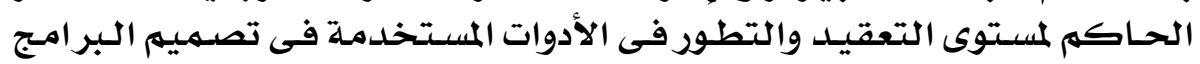

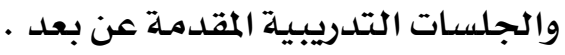

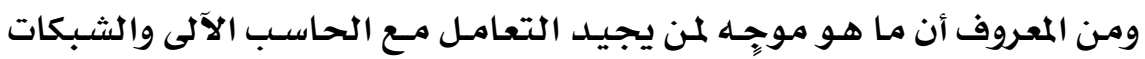

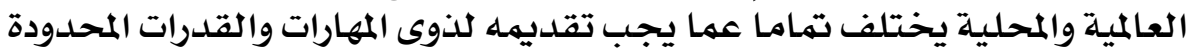

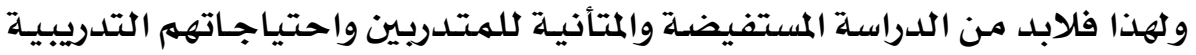

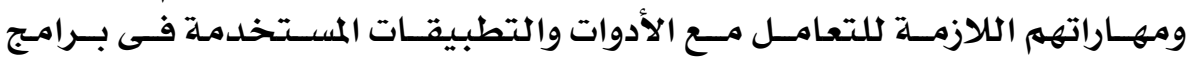

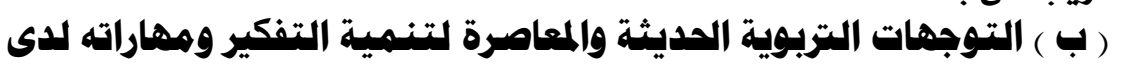

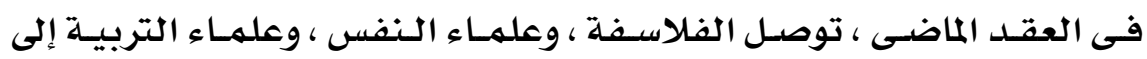

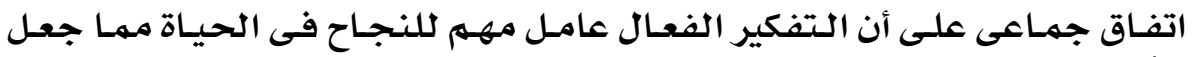

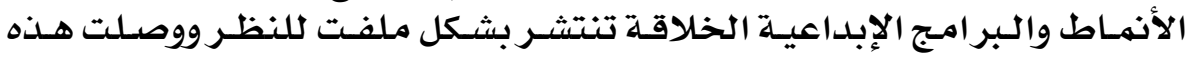

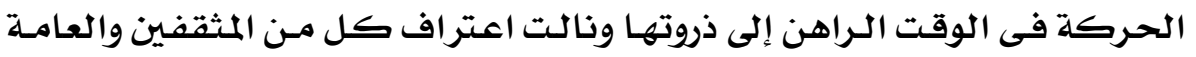

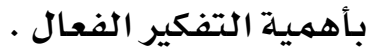

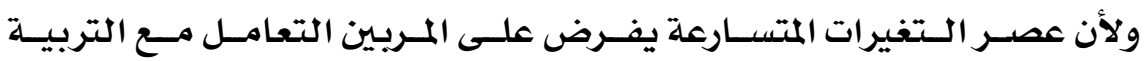

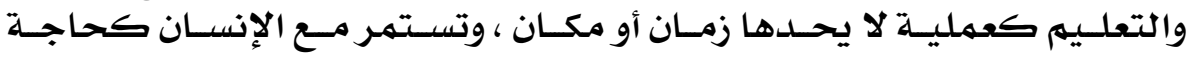

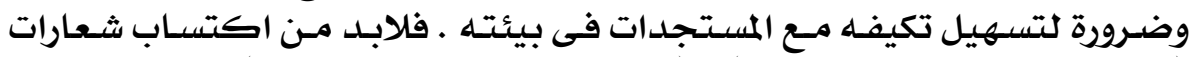

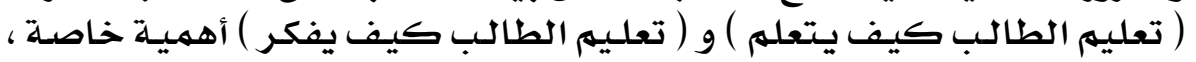

\section{$\varepsilon \vee \varepsilon$}




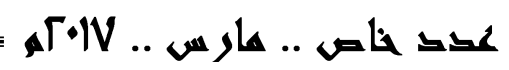

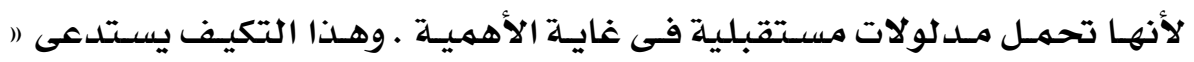

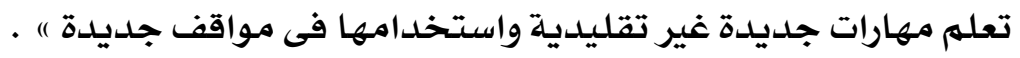

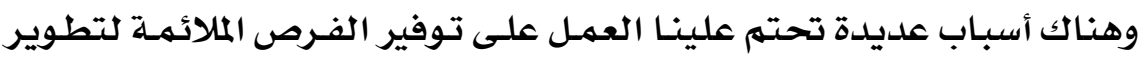

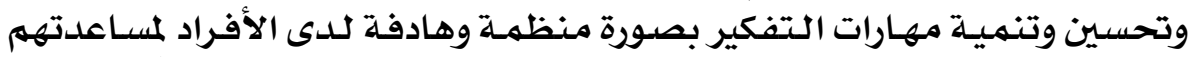

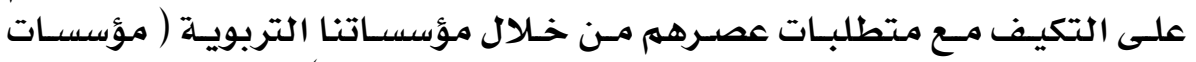

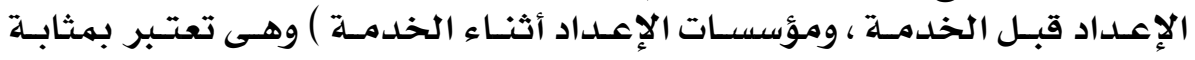

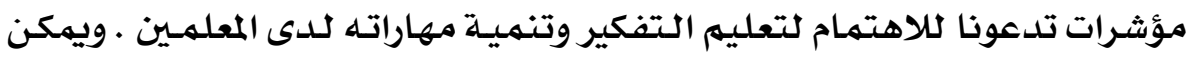

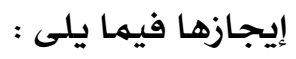

\section{• التفكير ضرورة حيوية للإيهان واكتساب نواهيس الحياة :}

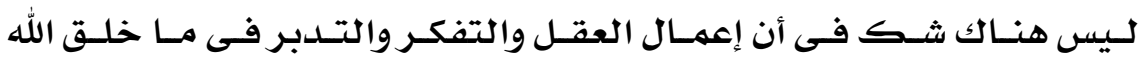

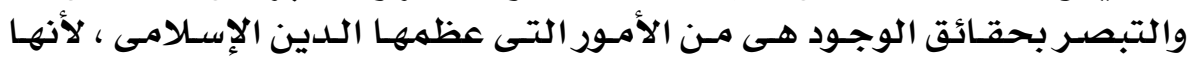

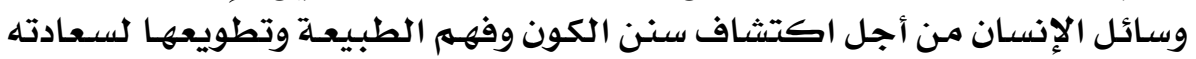

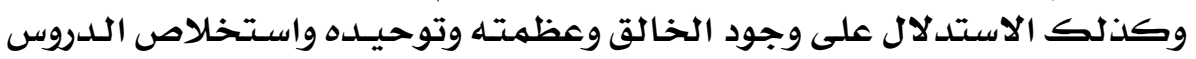

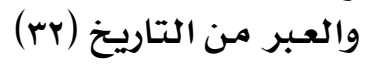

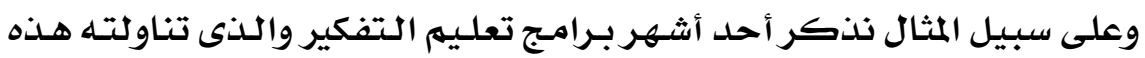

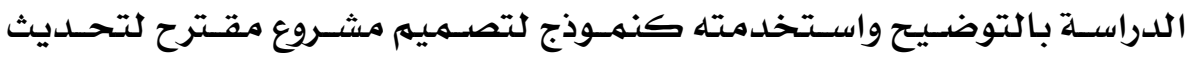

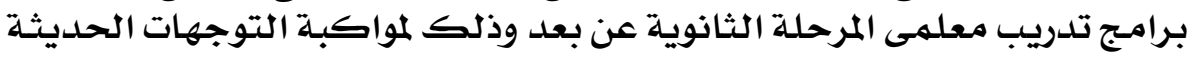

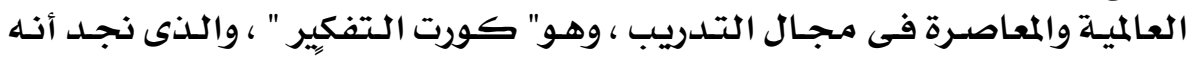

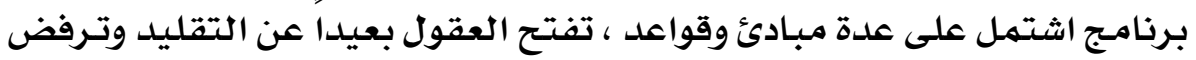

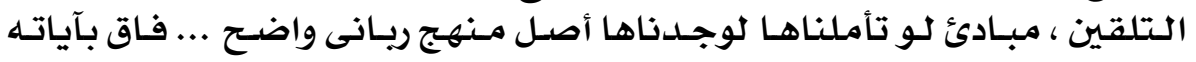

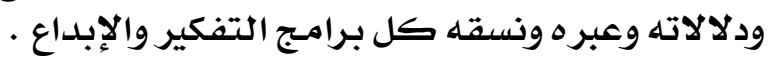

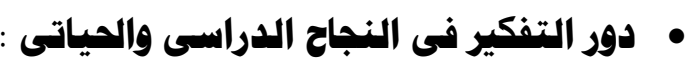

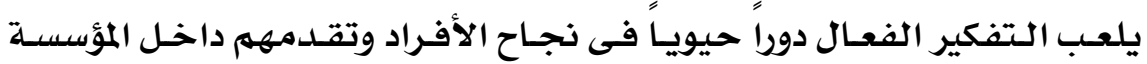

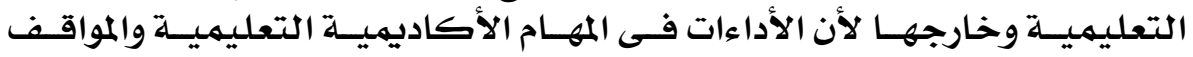

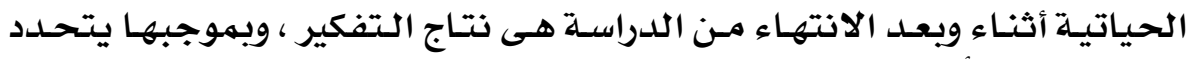

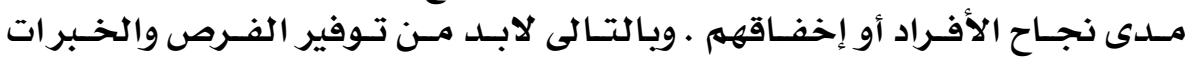

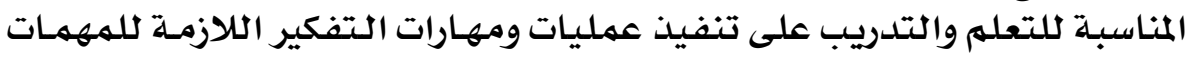

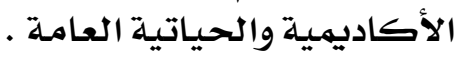

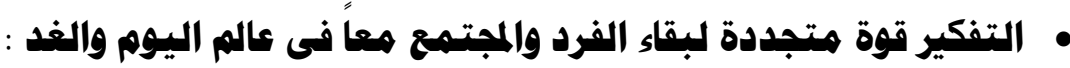

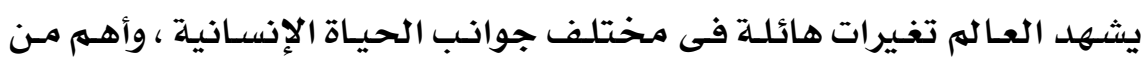

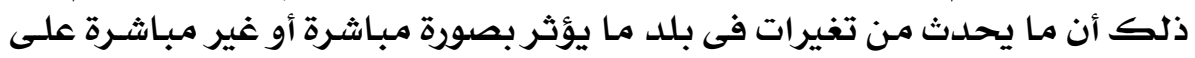

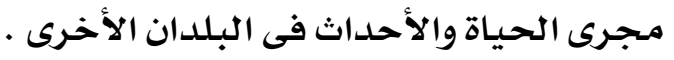

\section{$\varepsilon \vee \bullet$}




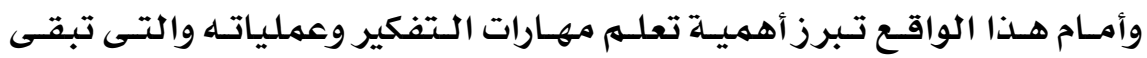

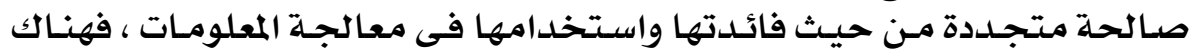

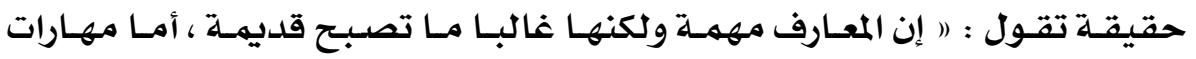

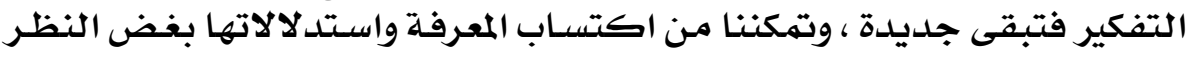

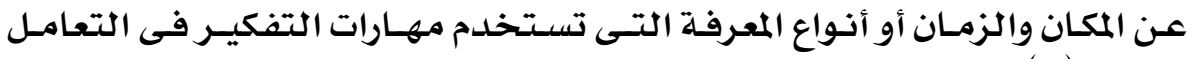

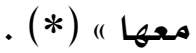

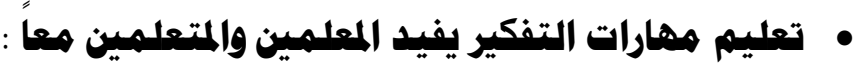

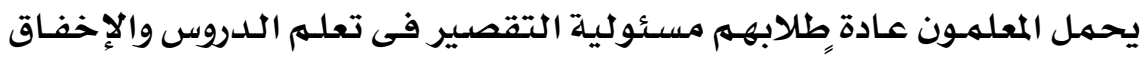

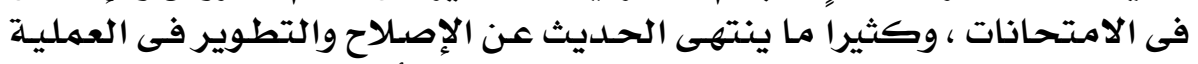

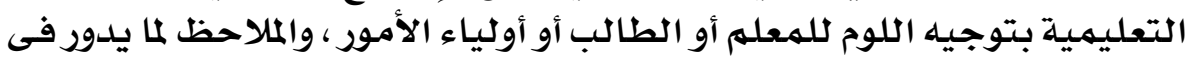

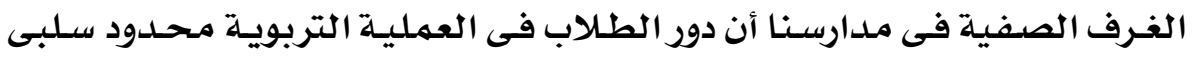

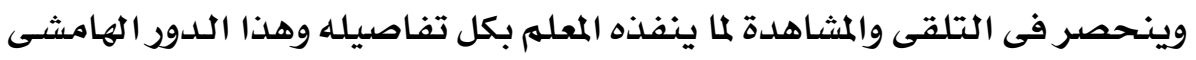

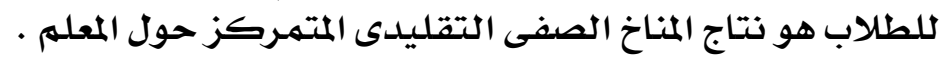

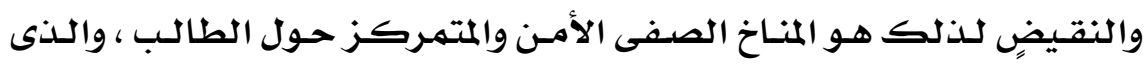

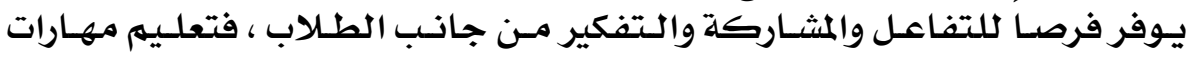

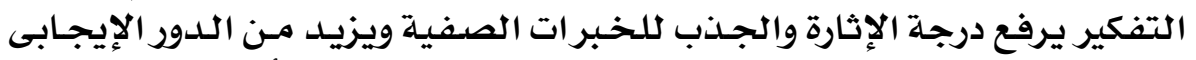

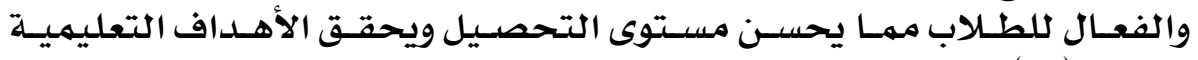

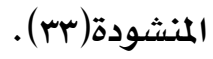

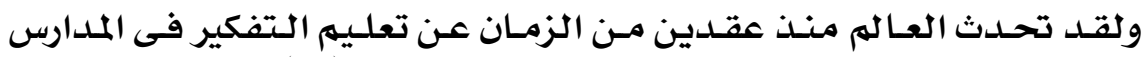

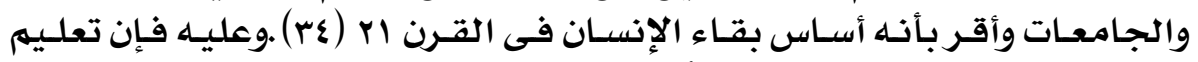

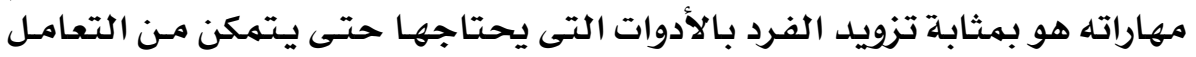

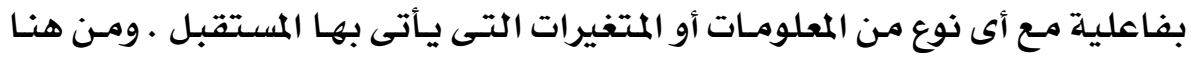

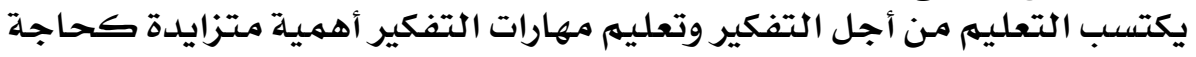

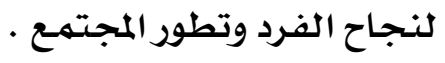

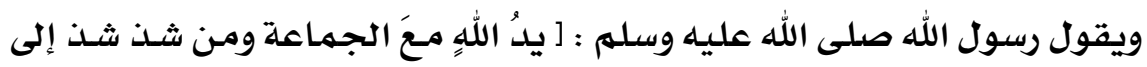
النار ] [ سنن الترمدئى وتعليهم التفكير قد يعنى للبعض تعليهم مهارات التفكير بشـكل مبـاشـر وصـريح

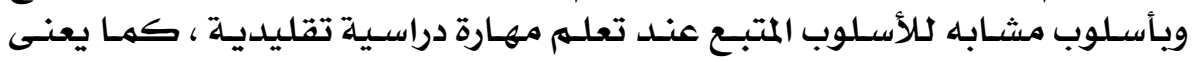

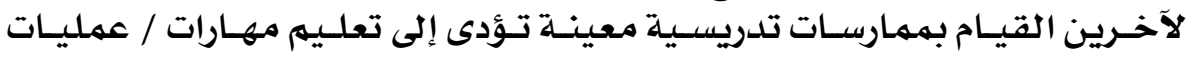

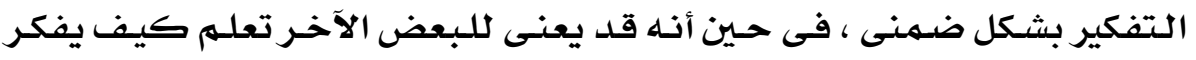

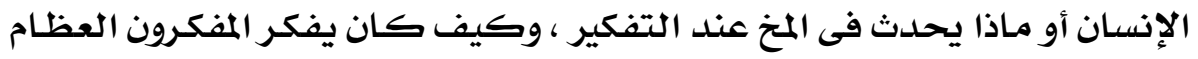

\section{$\varepsilon \vee 4$}




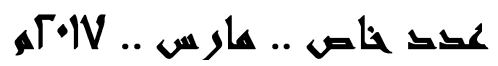

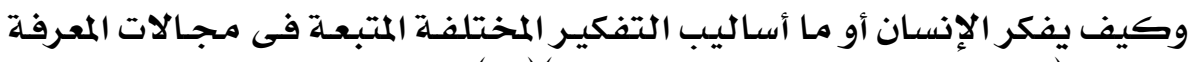

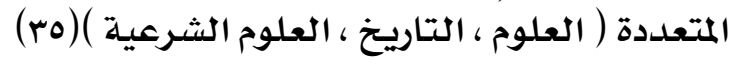

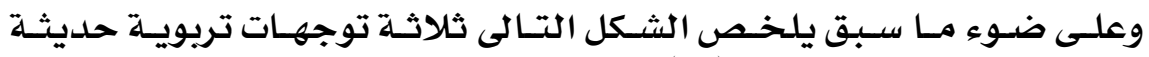

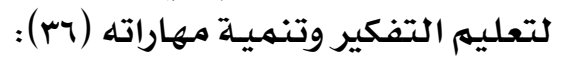
التوجهات التربوية لتنهية مهاراتهات (اتبة التفكير

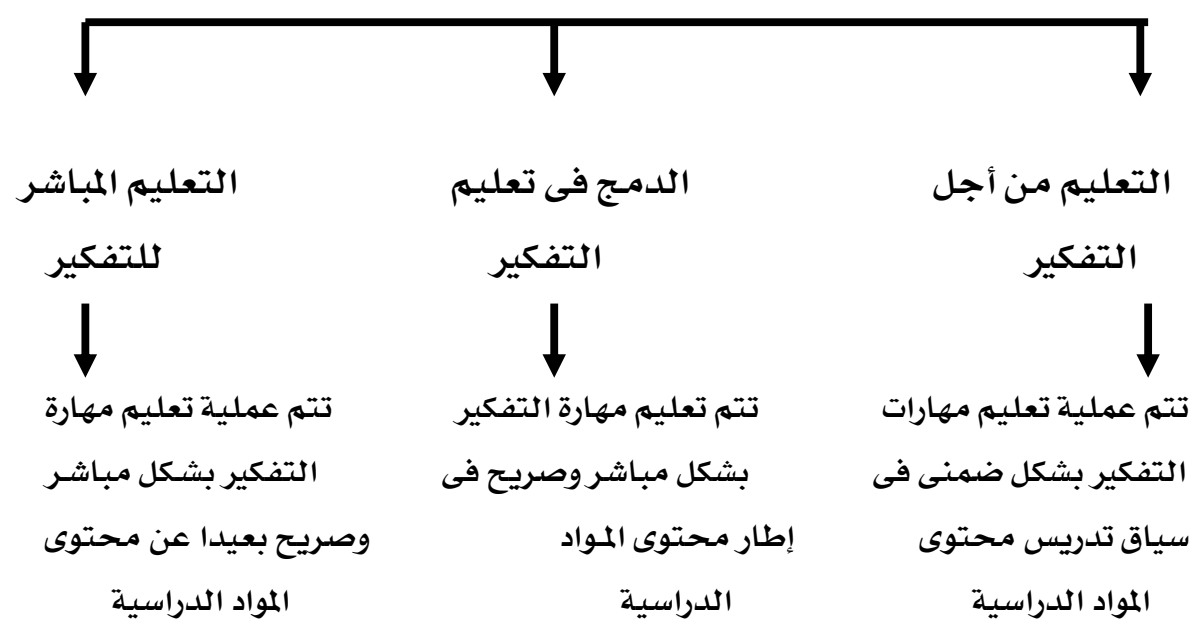

شكل (Y) : التوجهات التربوية الحديثة لتنمية مهارات التفكير

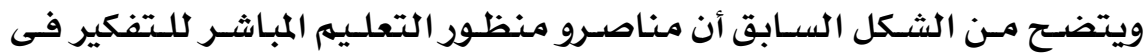

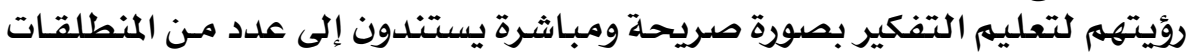

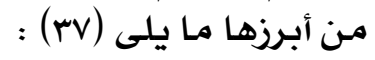

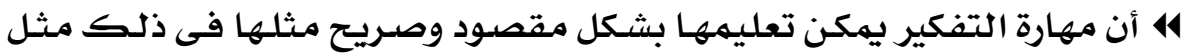

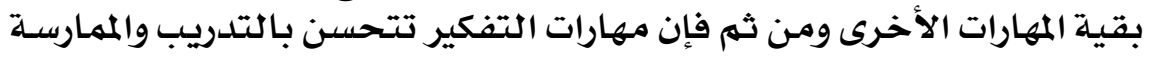

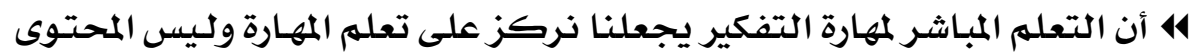

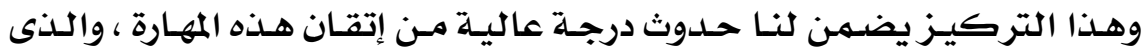

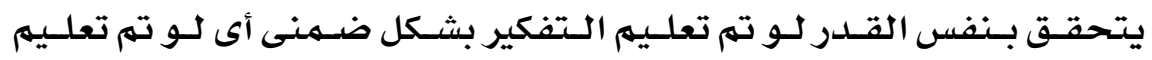

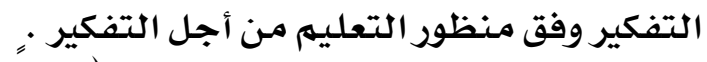

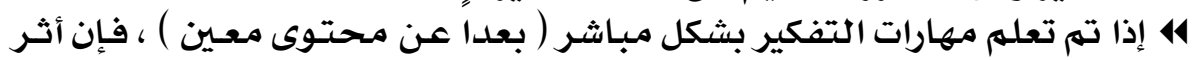

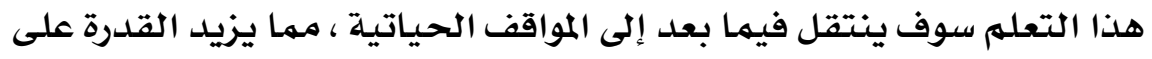

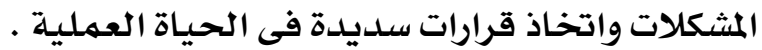
وعمليـة التعليهم والتعلهم محكومـة بعوامـل عديـدة تشـكل في مجملـها الإطـار

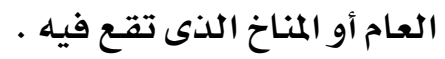

\section{$\varepsilon V V$}




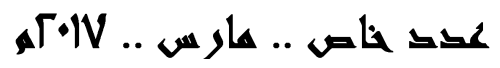

وتتلخص عوامل نجاح منظور التعلم المباشر لمهارات التفكير فيها يلى(ی) :

:

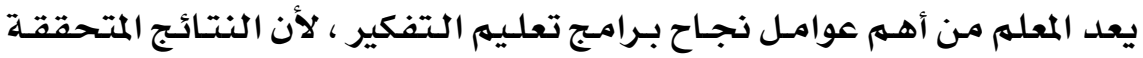

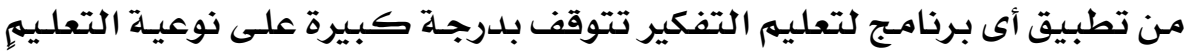

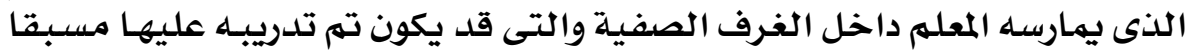

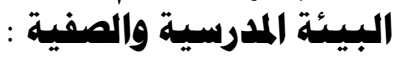

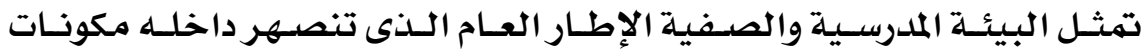

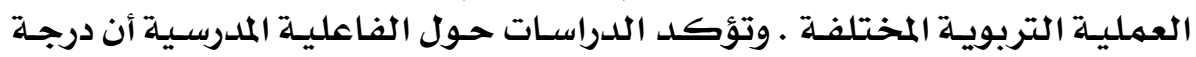

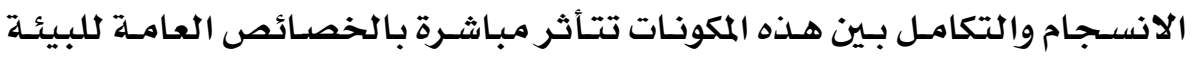

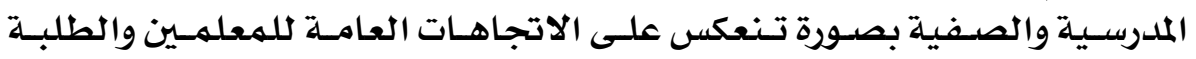

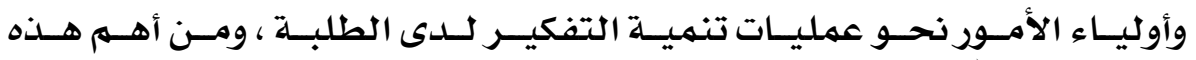

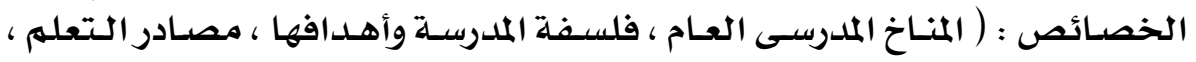

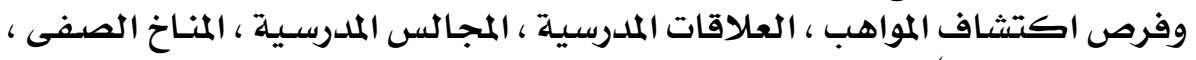

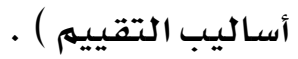

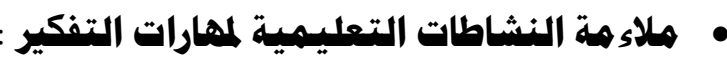

تختلف النشـاطات الملائمــة لتعلـيهم مهارات التفكير عن غيرهـا مـن النشـاطات

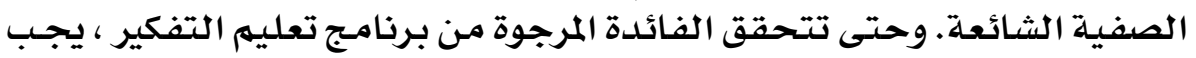

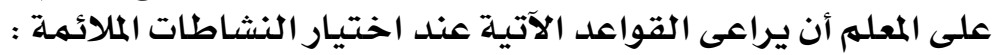

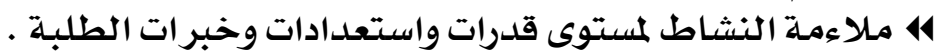

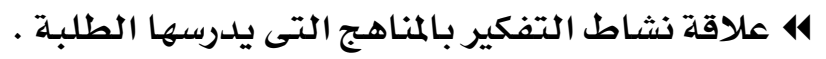
14

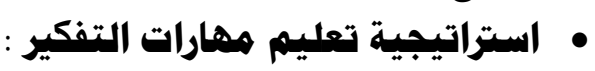

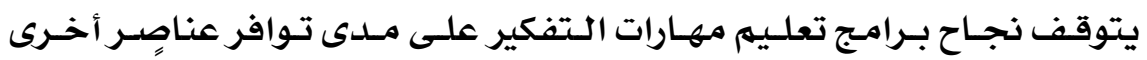

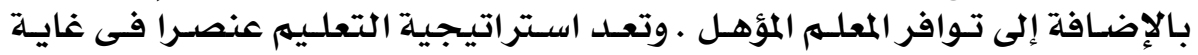

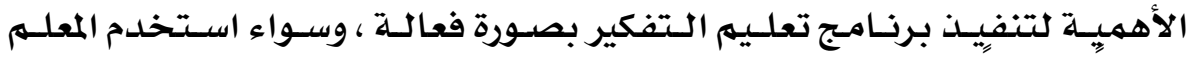

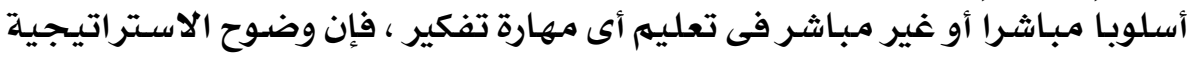

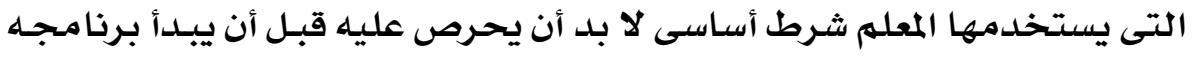

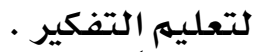

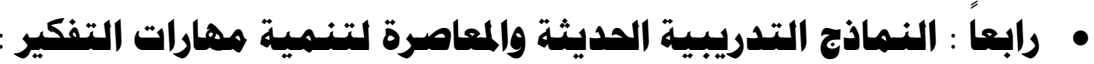

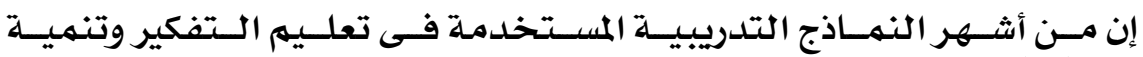

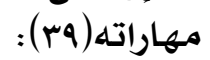

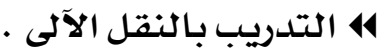

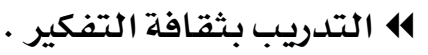

\section{$\varepsilon \vee \wedge$}




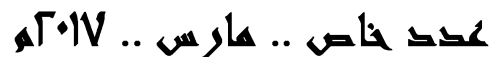

ويهكن توضيح الفرق بين النهوذجـين مـن خلال الجدول التالى :

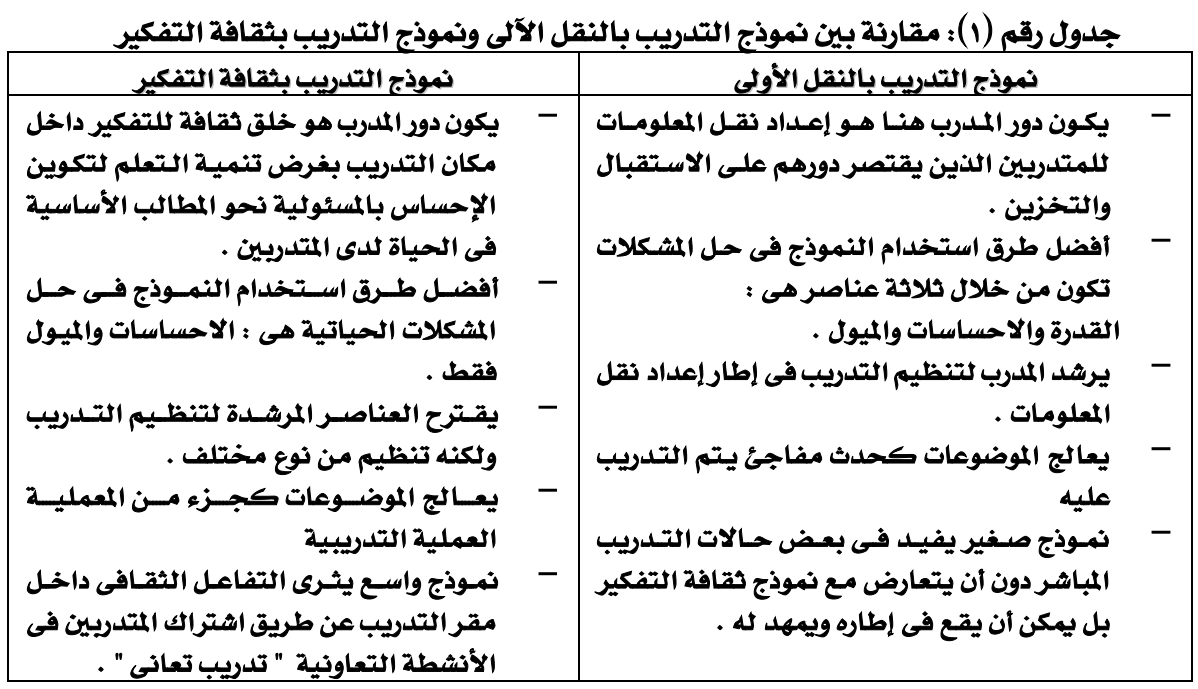

ومن المقارنة السـابقة يتضح أن : ومـن المقارنة السـابقة يتضع أن : نهوذج النقل

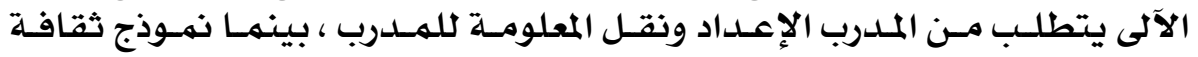

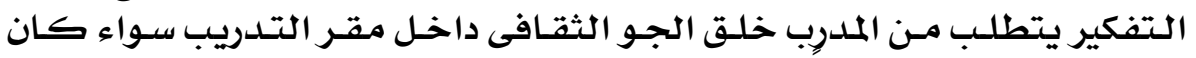

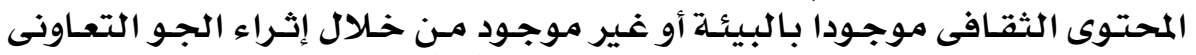

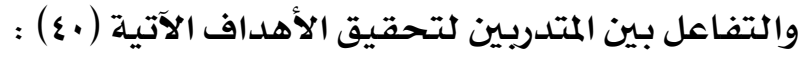

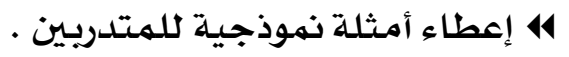

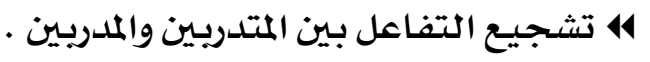
14 التتدريب المباشعر التفاعرل

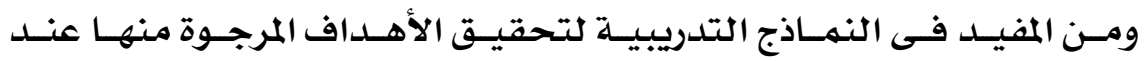

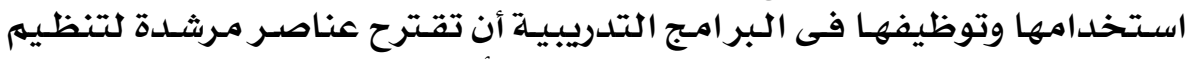

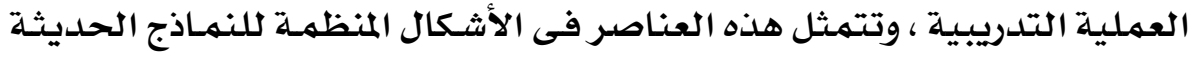

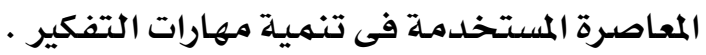

وتعـــ هـذه الأثـكال المنظهـة بهثابـة الإطـار الـذى يـنظم الـتفكير كعمليـة

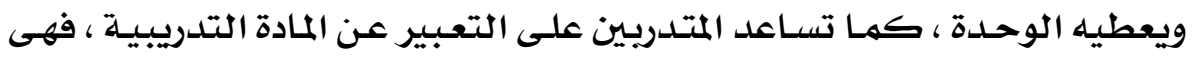

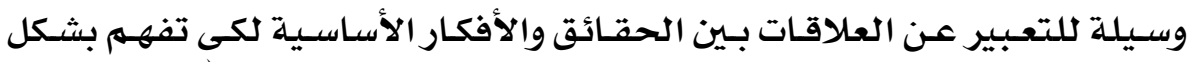

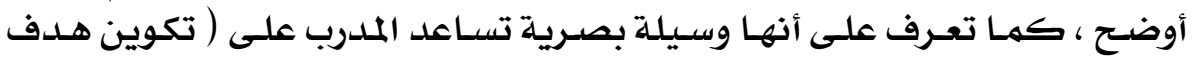

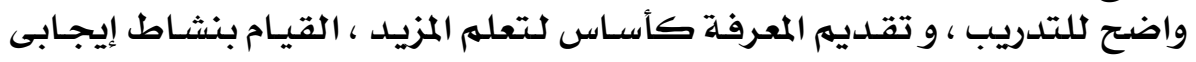

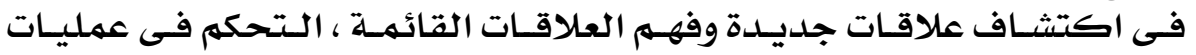

\section{$\varepsilon \vee q$}




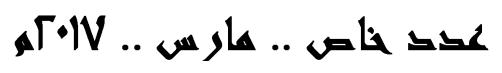

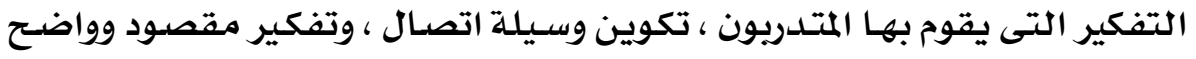

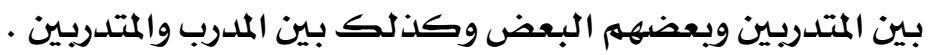

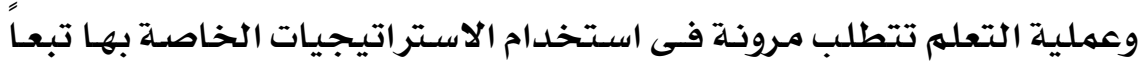

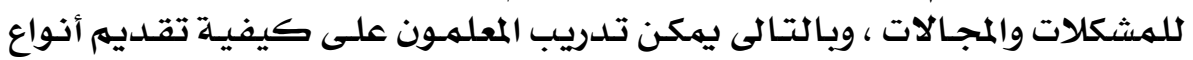

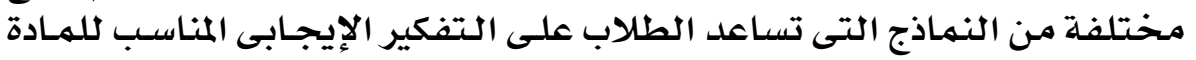

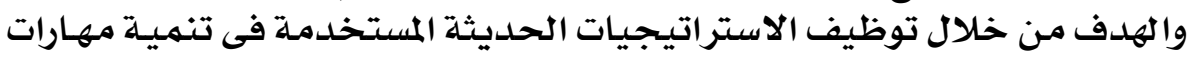

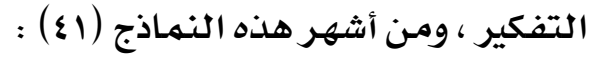
414

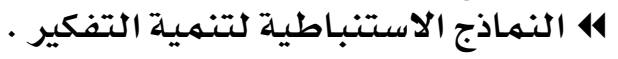

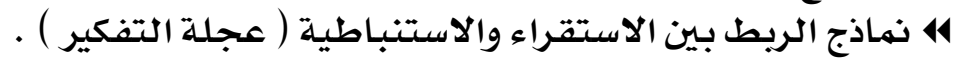

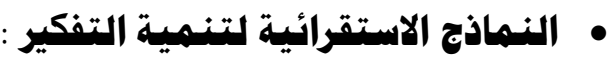

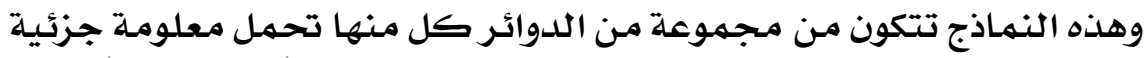

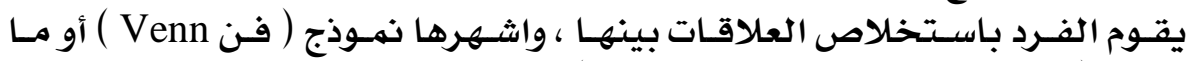
يعرف ( نموذج الدوائر لتوضيح العلاقات التونات ) . ويوضح الشكل التالى النمط الأساسى الذنى تبنى عليه هذه النماذج :

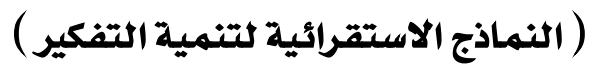

عرض البيانات وانتقائها

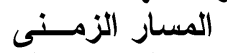

مسار الآجباء

مصفوفة بيانات

تكوين الفئات والمفاهيم أستخدام الدوائر

نموذج إيفر

نموذج فن

التفكير الاستعارى

استخلاص العلاقات الاتعارث

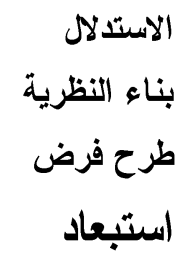

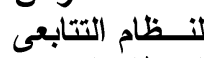

\section{(1)} الأحداث المتكررة

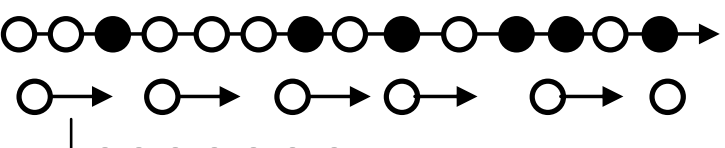

\section{0}
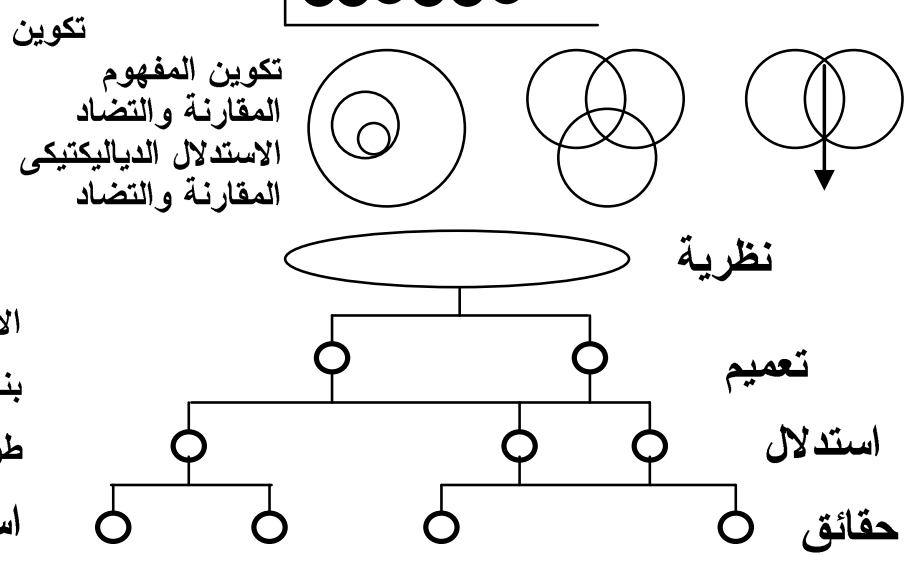

ثكل (r) : النمط الأساسى لبناء النماذج الاستقرائية لتنمية التفكير

\section{$\varepsilon \wedge$.}




$$
\text { عقد خاص .. عارس .. VIVזم, }
$$

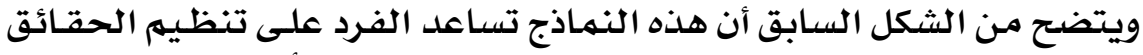

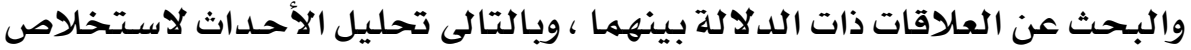

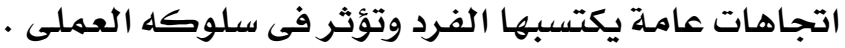

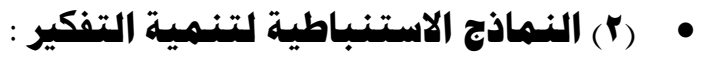

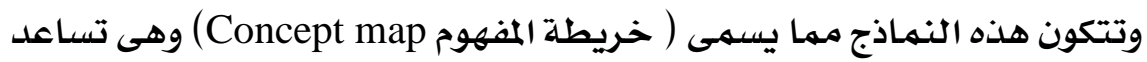

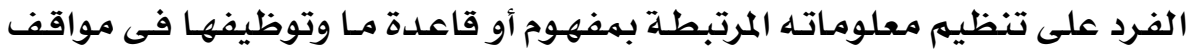

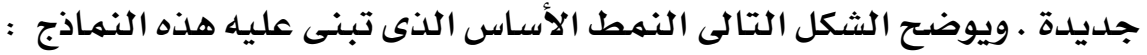

\section{(نماذج التفكير الاستنباطية لتنمية التفكير)}

بناء علاقات شبكية بين المفاهيم

بناء علاقات السبيبة ( سبب / نتيجة ) تخطيط تجميعى ربط المفاهيم بالحقائق

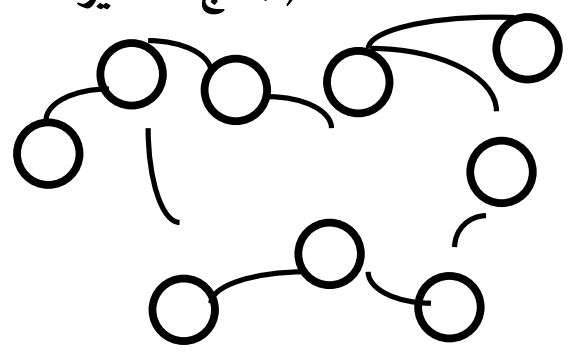

تطبيقات التفكير السببى

وضع مخطط

خرائط

منطق بما أن - إذن إن إن تحليل العلاقات ألسبيية ( سبب / نتيجة ) التبؤ بالوقائع

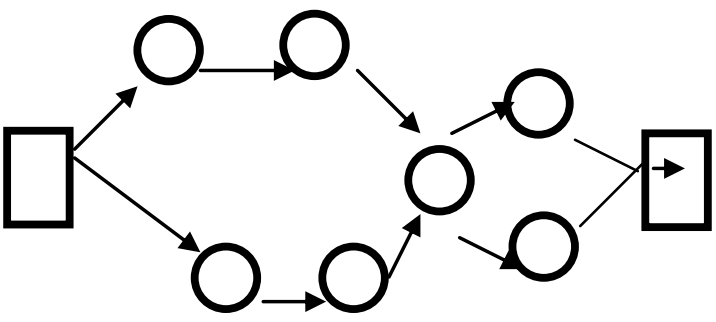

التخطيط رجل المشكلات

خطوات التخطيط رسوم تحديد الإجزاءات تعليل المهام رسوم بيانية
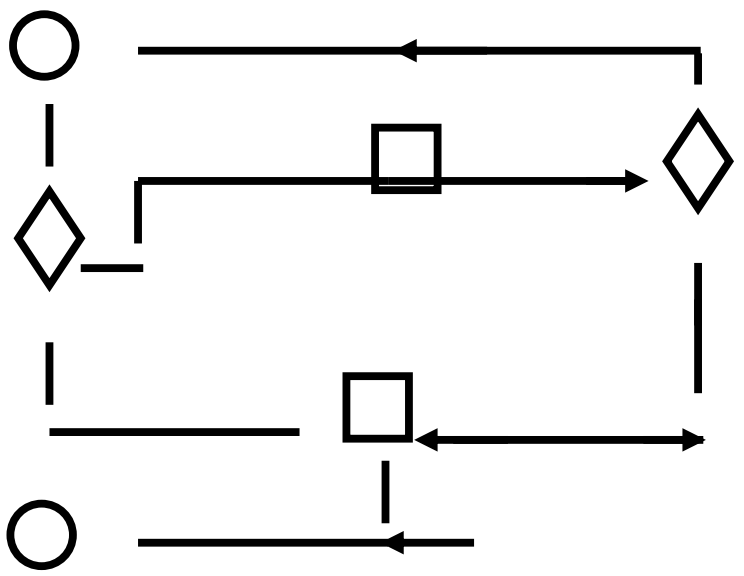

شكل (ع) : النمط الأساسى لبناء النماذج الاستنباطية لتنمية التفكير

\section{$\varepsilon \wedge 1$}

أوراق عهل وبموث المؤتهر الدولي الأول لمركز تنسية قدرات أعضاء هيئة التدريس والقيادات بجاهعة بنها .. 9 هارس I ا. بمم 


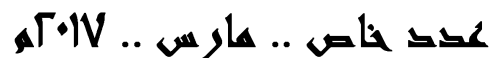

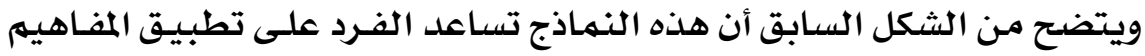

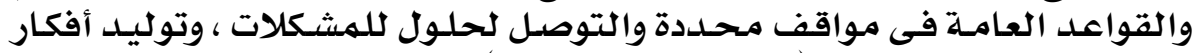

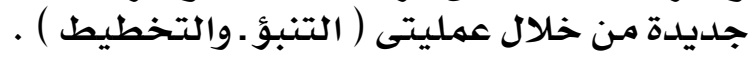

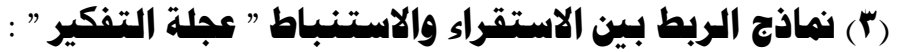

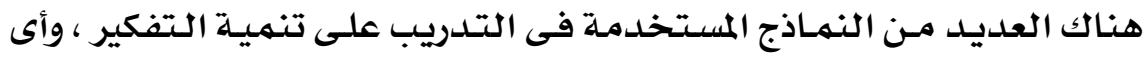

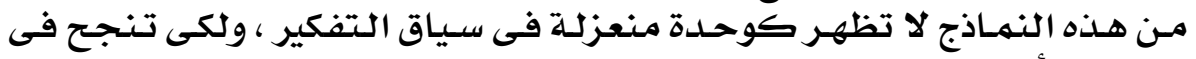

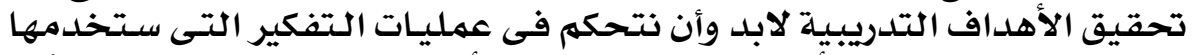

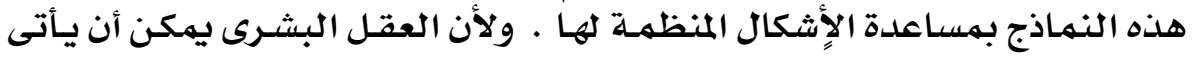

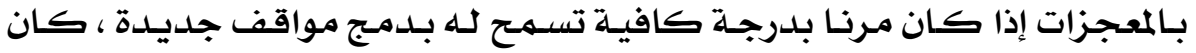

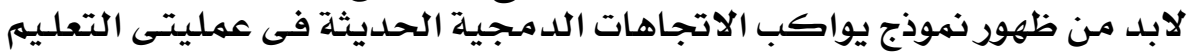

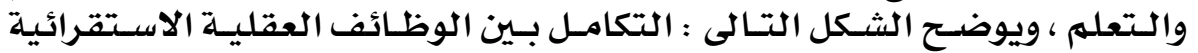

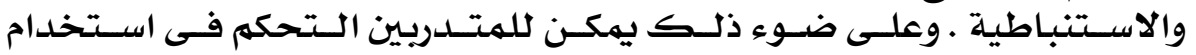

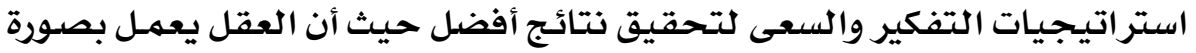

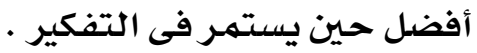

نماذج الربط بين الاستقراء والاستنباط فى تنمية التفكير

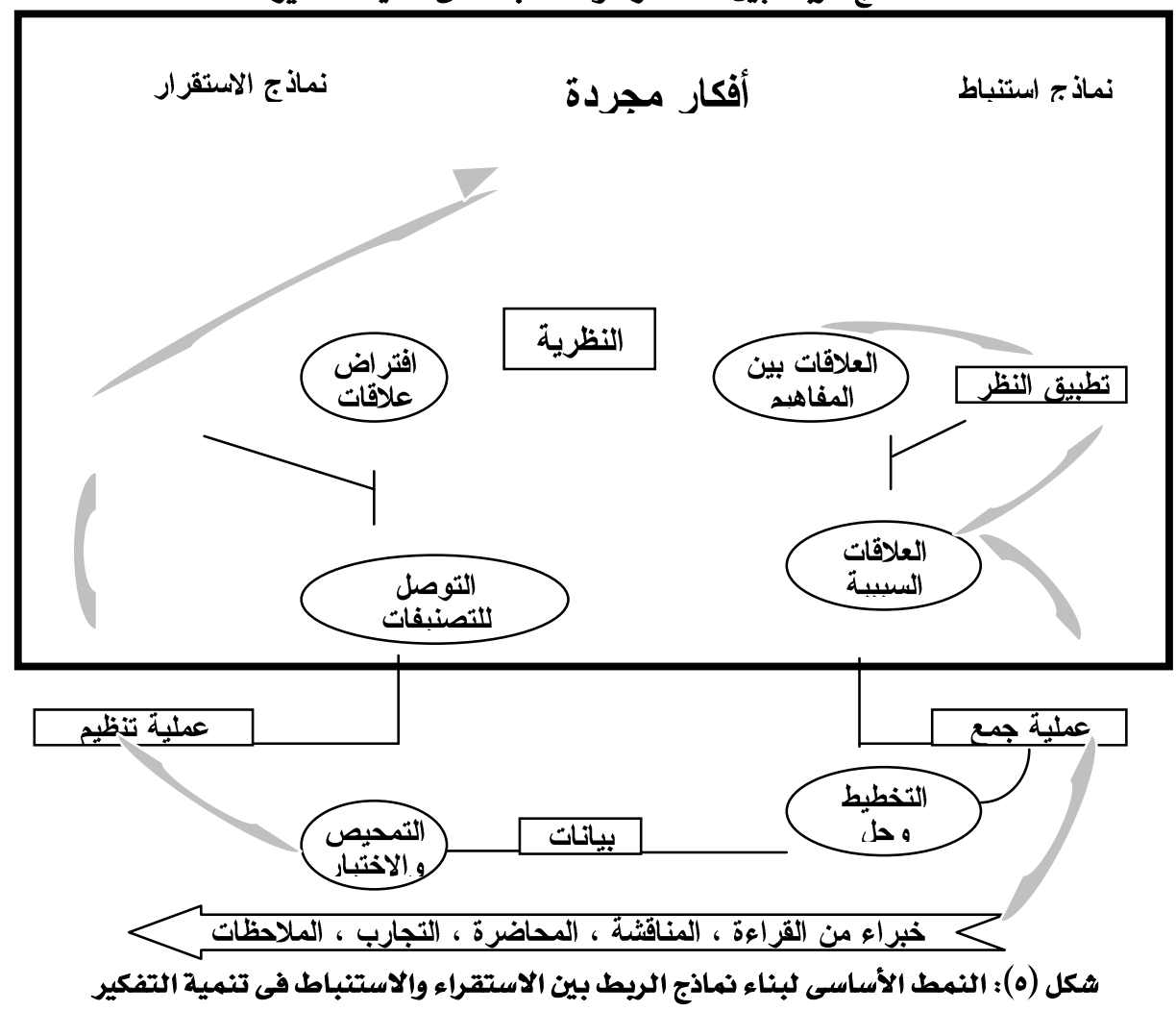

\section{$\varepsilon \wedge Y$}




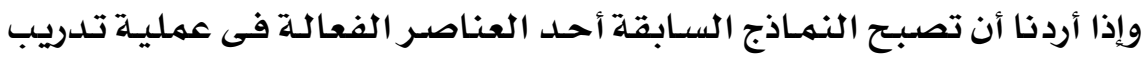

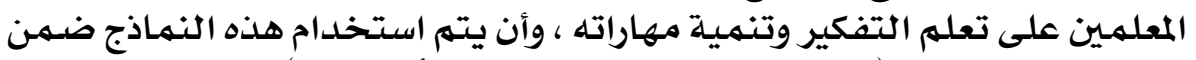

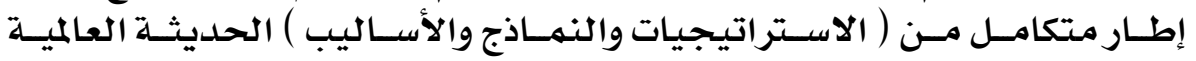

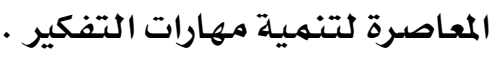

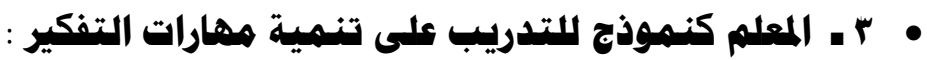

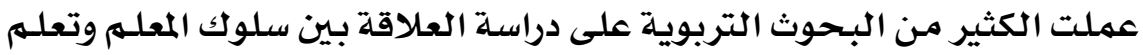

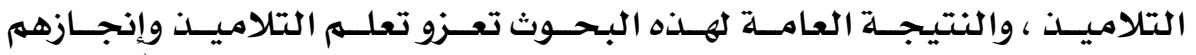

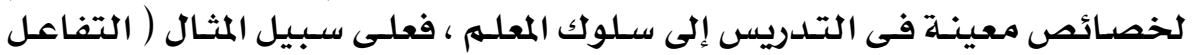

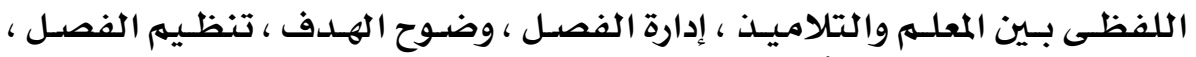

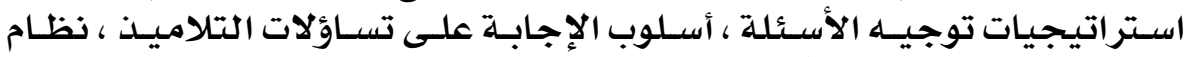

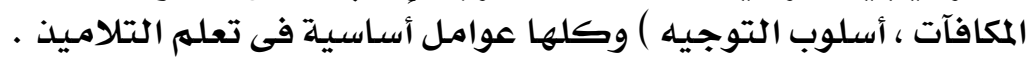

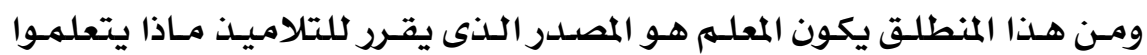

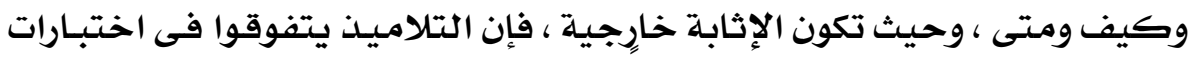

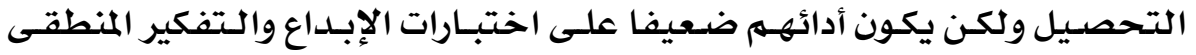

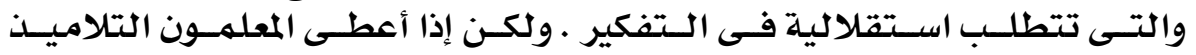

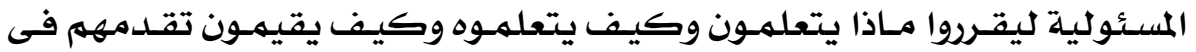

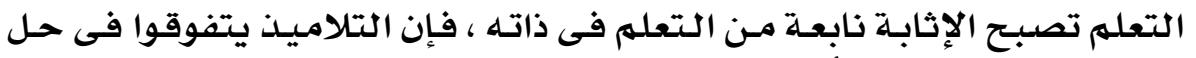

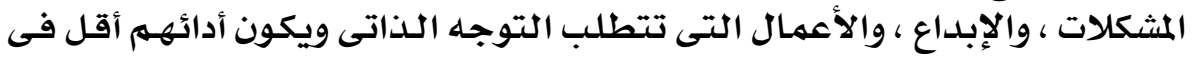

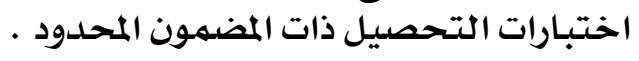

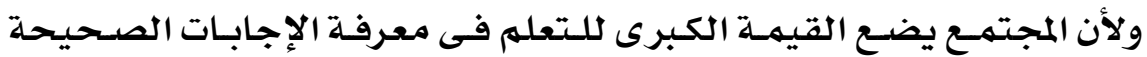

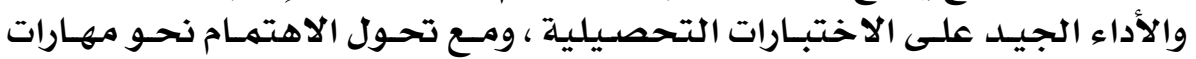

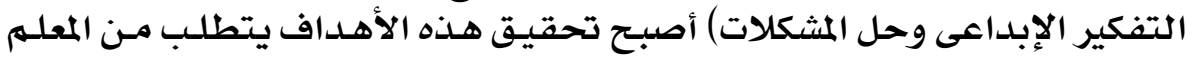

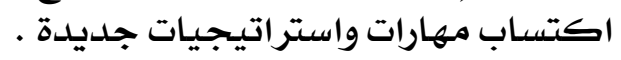

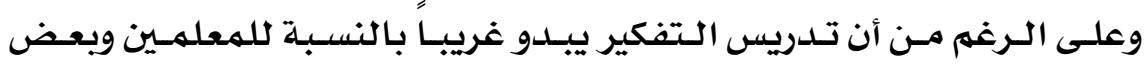

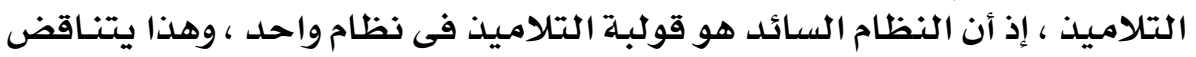

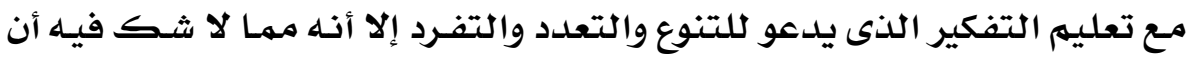

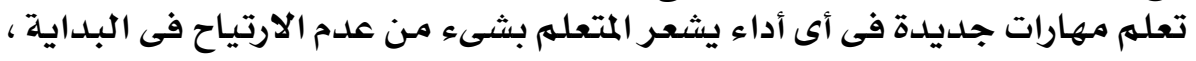

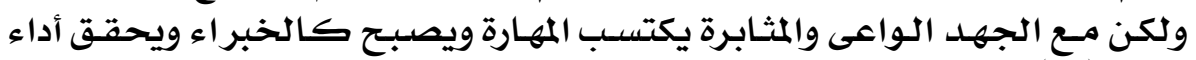

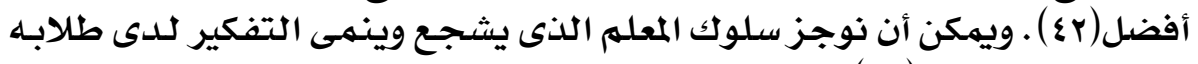

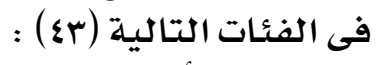

414 نوجيه الأسئلة : Q

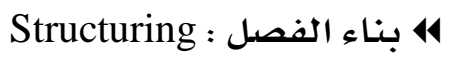

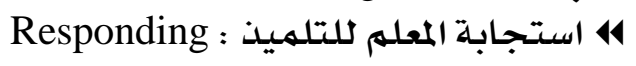

\section{$\varepsilon \wedge r$}




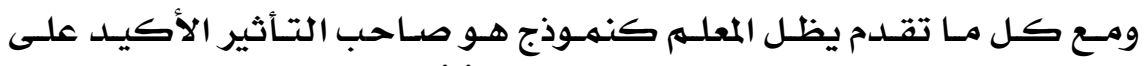

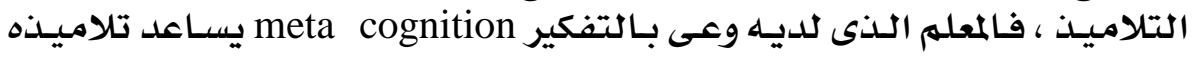

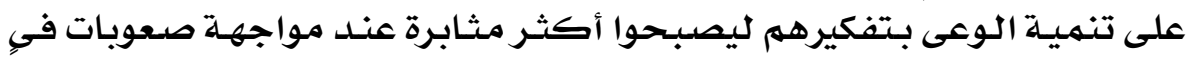

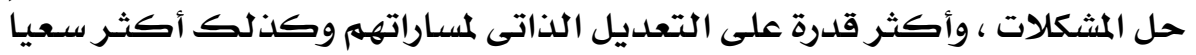

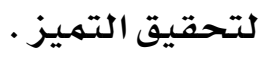

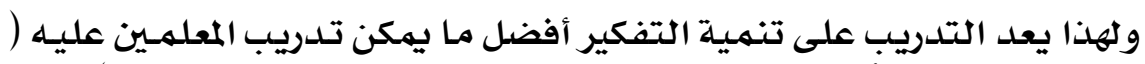

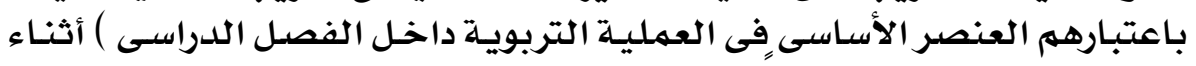

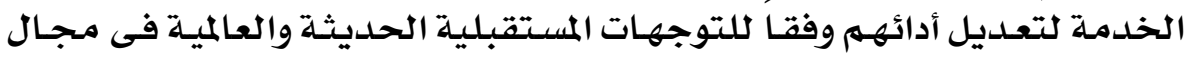

$$
\text { • التدريب عن بعد . التوصيات : التعد }
$$

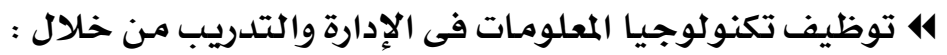

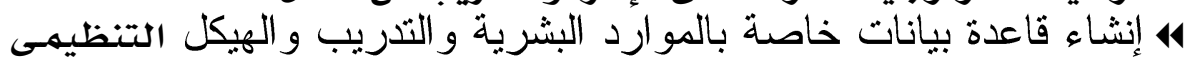

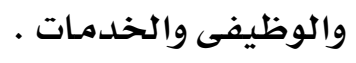

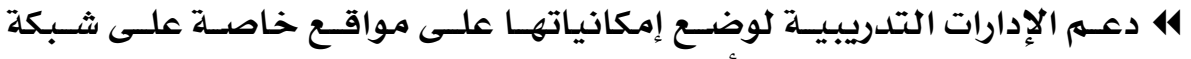

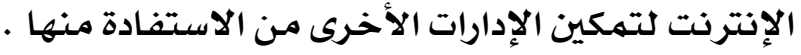

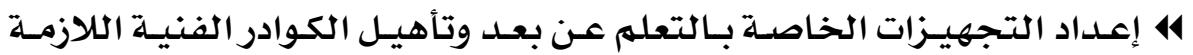

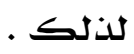

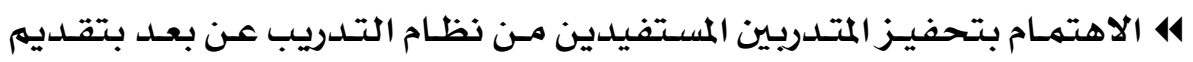

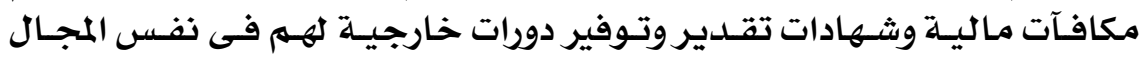

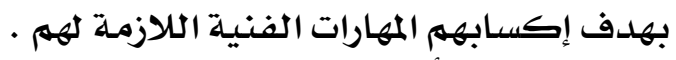

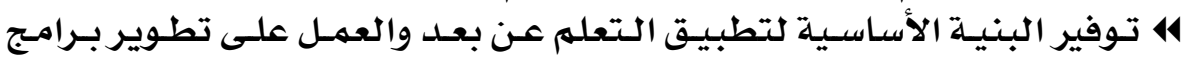

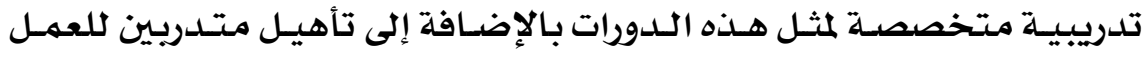

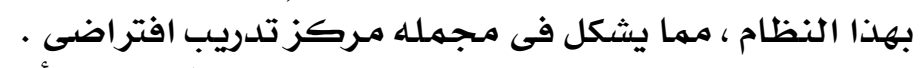

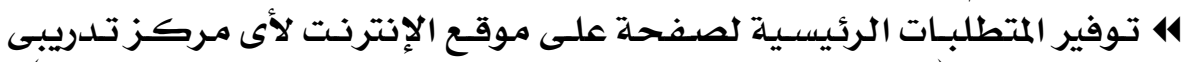

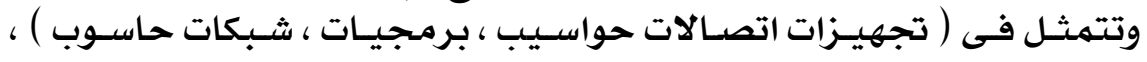

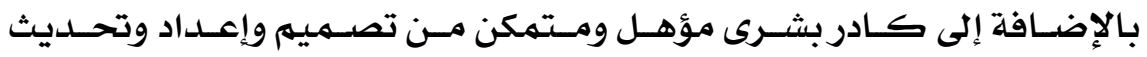

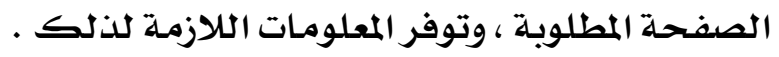

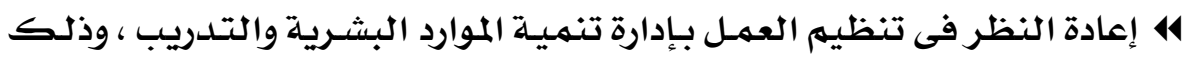

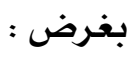
4 لهديث الوصف الوظيفى بصورة دوريـة تتفق مـع أهداف واحتياجـات التطور

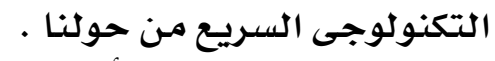
41 التركيز على مؤشرات الأداء ووضع أسس واضحة لها لها .

\section{$\varepsilon \wedge \varepsilon$}




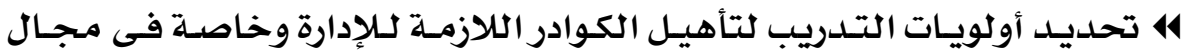

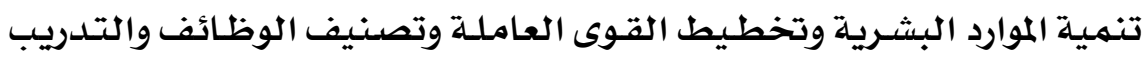

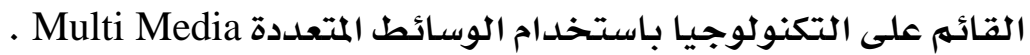

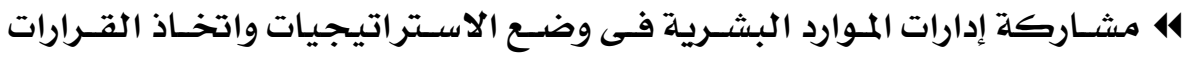

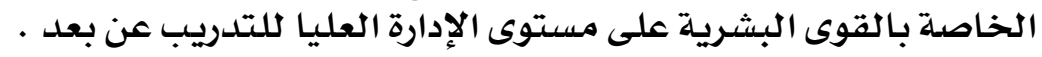

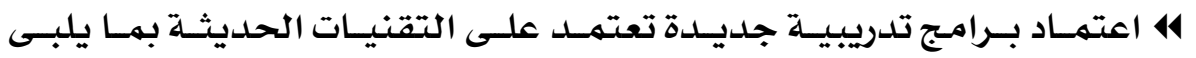

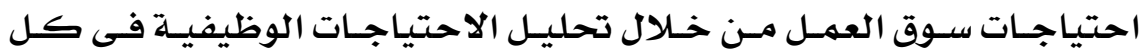

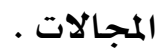

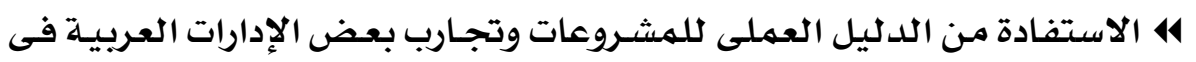

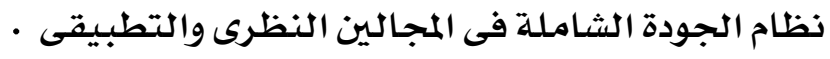

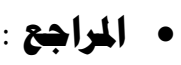

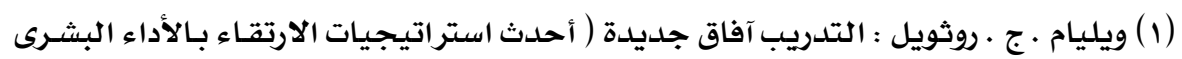

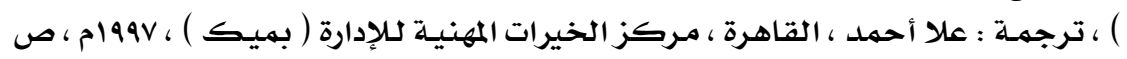

(2) Cameron K.: "Critical Questions in assessing Organizational effectiveness, in Organizational Dynamics, autumn, 1980, P. P. 66-80.

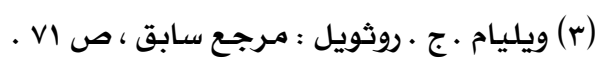

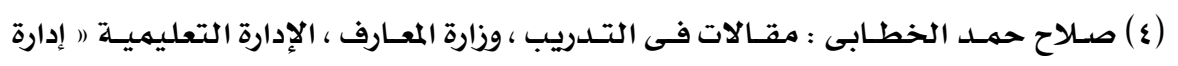

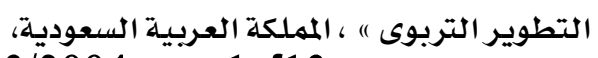
http://www.Kus.edu.Sa, 08/03/2004,page 1 of 13.

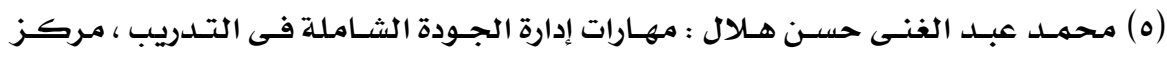

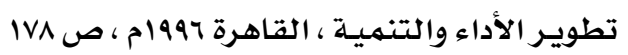

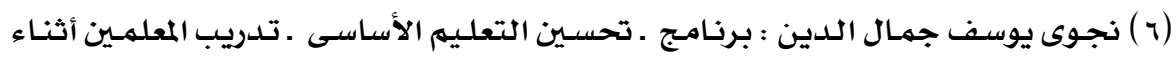

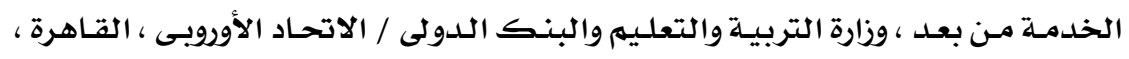

م محمد عبد الغنى حسن هلال : مرجع سـابق ، ص (v)

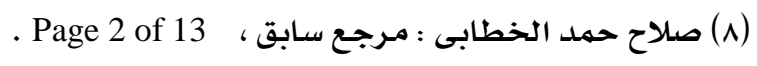

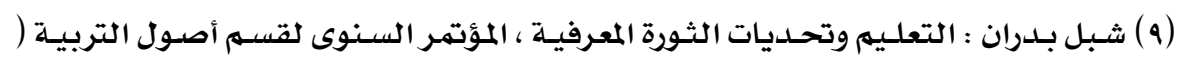

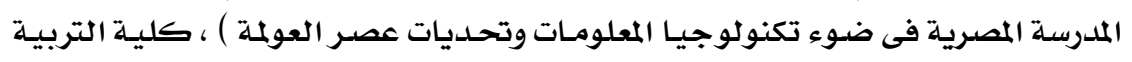

\section{$\varepsilon \wedge \odot$}




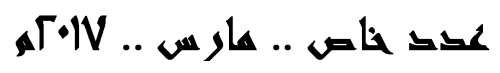

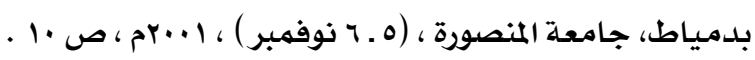

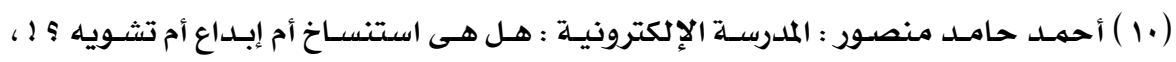

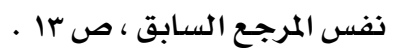

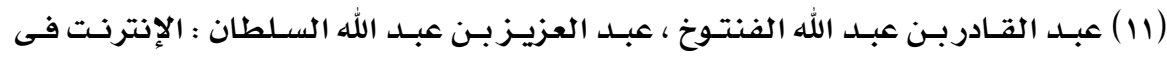

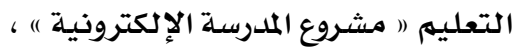
http://www.ecoworld-mag.com, 12/04/2004,page 2 of 18 .

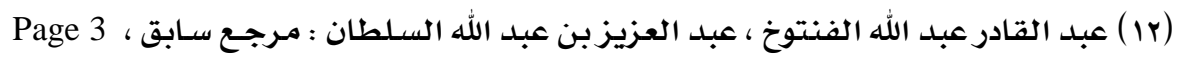
. of 18

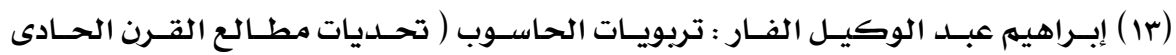

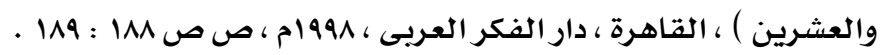

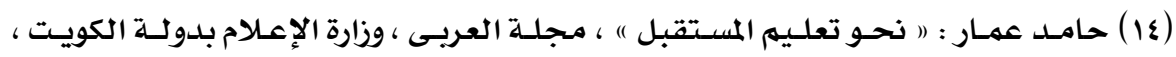

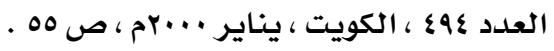

(10) محمد رضا البغدادى : تكنولوجيا التعليهم والتعلهم ، القـاهرة ، دار الفكر العربى ، 1999ام

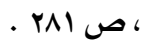

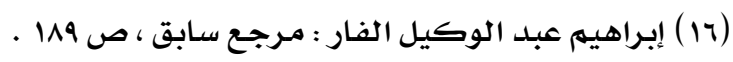

(IV)

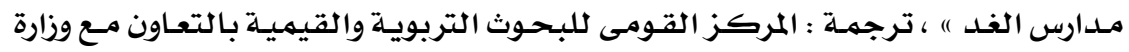

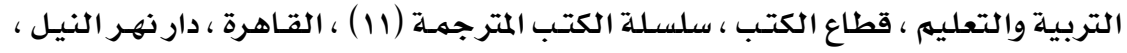

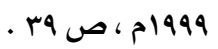

$$
\text { (11) أحمد زكى بدوى : مرجع سـابق ، ص }
$$

(19) بيـل جيـتس : المعلومـاتيـة بعـد الإنترنت ، ترجمـة : عبــ السـلام رضـوان ، الكويـت ، عـالم

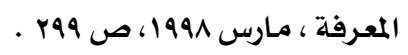

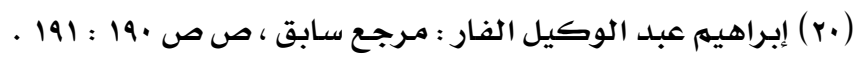

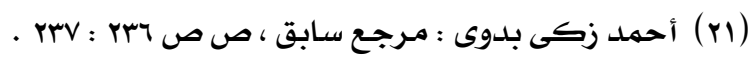
(r ) إبراهيم عبد الوكيل الفار : مـرجع سابق ، ص آ .

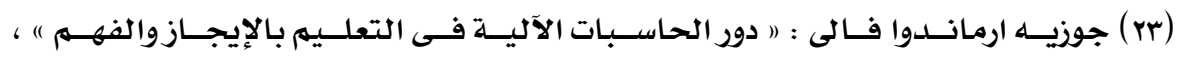

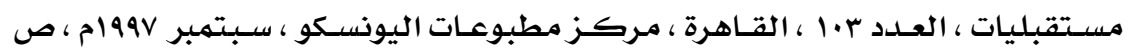

\section{$\varepsilon \wedge 7$}




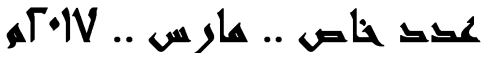

$$
\begin{aligned}
& \text { (r ) إبراهيم عبد الوكيل الفار : مـرجـع سابق ، ص } 191 \text {. } \\
& \text { (ro) إبراهيه عبد الوكيل الفار : مرجع سـابق ، ص ص } 191 \text { : 19r . }
\end{aligned}
$$

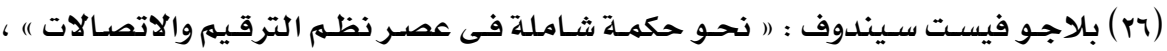

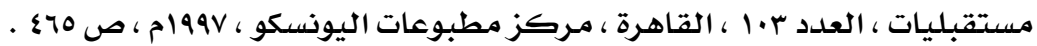

$$
\text { إبراهيهم عبد الوكيل الفار : مـرجع سابق ، ص } 190 \text { (rV) }
$$

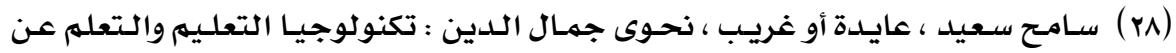

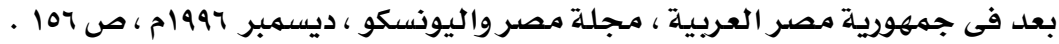

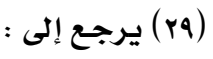

$$
\text { بلاجو فيست سيندوف : مرجع سابق ، ص }
$$

إبراهيهم عبد الوكيل الفـار : مـرجع سـابق ، ص ص 190 : 177 .

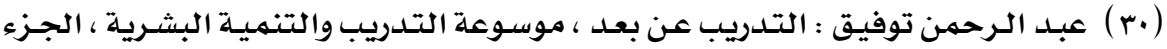

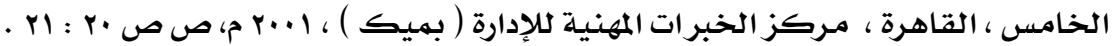

$$
\text { ( اسץ) عبد الرحمن توفيق : التدريب عن بعد ، مـرجـ سابق ، ص ص 0ب : اس . }
$$

(rr) فتحسى عبــ الـرحمن جـروان : تعلـيم الـتفكير مفـاهيم وتطبيقـات ، العـين ، الإمــارات

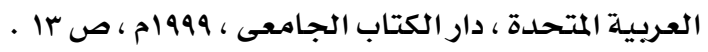

(rr) فتحى عبد الرحمن جردان : نفس المرجع السابق ، ص ص \&1 : 11 .

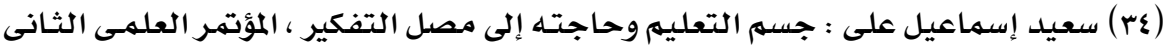

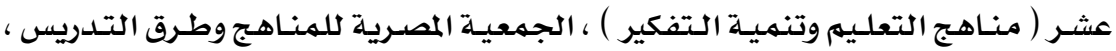

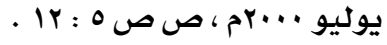

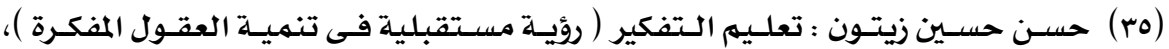

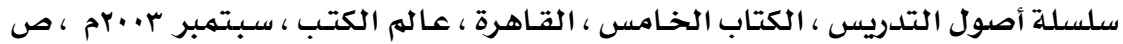

$$
\begin{aligned}
& \text { ( حس) المرجـع السـابق ، ص r.1 . } \\
& \text { : للاطلاع أنظر (rv) }
\end{aligned}
$$

$$
\text { فتحى عبد الرحمن جروان : مـرجـع سابق ، ص } 19 \text {. }
$$

Beyer, B. K.: What Research Says about Teaching Thinking Skills. In L. A. Costa (Ed.) Developing Minds: A Resource Book for teaching thinking 3rd ed., (2001 B), pp. 275-282.

\section{$\varepsilon \wedge \vee$}


عقد خاص .. هار س. .. VIיזم

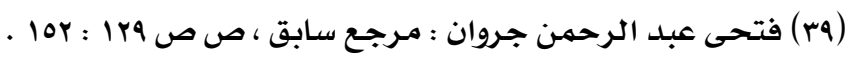

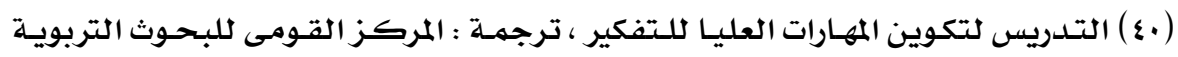

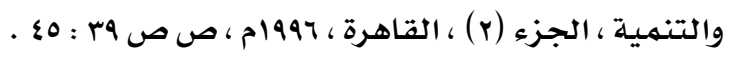

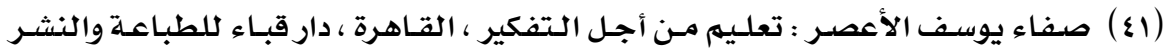

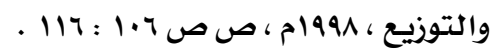

(42)Thomas, J.:" Agency and achievement: Self-Management and Self Regard", Review of Educational Research, (Summer. 1990), pp. 210: 213.

(43)Sanacore, J.: "Metacogition and the Improvement of Reading: SomeImportant Links", Journal of Reading, (May, 1994), pp. 706: 712.

\section{$\varepsilon \wedge \wedge$}

أوراق عهل وبموث المؤتهر الدولي الأول لمركز تنسية قدرات أعضاء هيئة

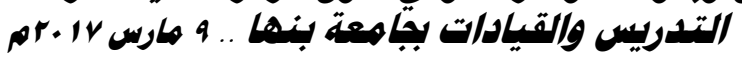

